MOĞOLİSTAN'DA ESKİ TÜRKLERE AİT YENİ ARKEOLOJİK BULUNTULAR*

Dovdoyn BAYAR ${ }^{* *}$

çev. Nurdin USEEV

\title{
Özet
}

Moğolistan topraklarında bulunan eski dönemlere ait arkeolojik eserlerin büyük bir kısmı Köktürklere ve Uygurlara aittir. Söz konusu dönemlere ait eserlerin araştırılıp incelenmesi XIX. asrın sonunda başlayıp bugüne kadar da başarıyla devam etmiştir.

Bu makalede son yıllarda Moğolistan'da bulunan ve Moğolistan dışında iyi bilinmeyen yeni arkeolojik keşifler (anitlar, yazıtlar, kurganlar, yer altı mezarları, kaya mezarları ve kazılar) hakkında bilgi verilmektedir.

Anahtar Sözcükler: Moğolistan, Eski Türk dönemi, Uygur, Köktürk, arkeoloji, buluntu

\section{NEW ARCHAELOGICAL DISCOVERIES RELATED TO OLD TURKS IN MONGOLIA}

\begin{abstract}
A major portion of archaelogical monuments that have been found in Mongolia are related to KokTurks and Uigurs. Examining of these monuments started at the end of the $19^{\text {th }}$ century and continues successfully nowadays.

In this article we inform about new archaelogical discoveries (monuments, inscriptions, eairns, underground tombs, rock-cut tombs, and excavations) found in Mongolia and not well-known outside of the Mongolia.
\end{abstract}

Keywords: Mongolia, old Turkish period, Uigur, KokTurk, archaelogy, discovery.

\section{Olon Nuur Vadisi'ndeki Eski Türk Anıtı}

2008 y1lında Moğolistan Bilimler Akademisi Arkeoloji Enstitüsü arazi ekibi tarafından Bayanhongor Aymag'daki Galuut Sum topraklarında bulunan Olon Nuur arazisindeki bir eski Türk mezar-kült kompleksi incelenmiştir. Bu mezar kompleksi ne yazık ki birkaç yıl önce kimliği belirsiz kimseler tarafından tahrip edilmiştir.

Anıt mezar kompleksi yağmacıların sistemsiz kazıları sonucu büyük tahribata uğramış; merkezinde derin bir çukur oluşmuştur.

\footnotetext{
* Bu yazı 13-15 Ekim 2010 tarihinde Afyon Kocatepe Üniversitesi tarafindan düzenlenen Uluslararası Zeki Velidi TOGAN ve Türk Kültürü Sempozyumu'nda bildiri olarak sunulmuş; daha sonra Dr. Nurdin USEEV tarafindan Rusçadan Türkçeye çevirisi, Dr. Cengiz ALYILMAZ tarafindan da düzenlemesi yapılmış ve görselleri eklenerek yayıma hazır hâle getirilmiştir.

** Prof. Dr.; Moğolistan Bilimler Akademisi Arkeoloji Enstitüsü Öğretim Üyesi. 1946 Ulaanbaatar doğumlu olan Prof. Dr. Dovdoyn BAYAR, 13-15 Ekim 2010 tarihinde Afyon Kocatepe Üniversitesinde yapılan sempozyumda bu bildirisini sunduktan sonra ülkesine dönmüş̧; 10.11.2010 tarihinde geçirmiş olduğu kalp krizi sonucu vefat etmiştir (C.A.).
} 


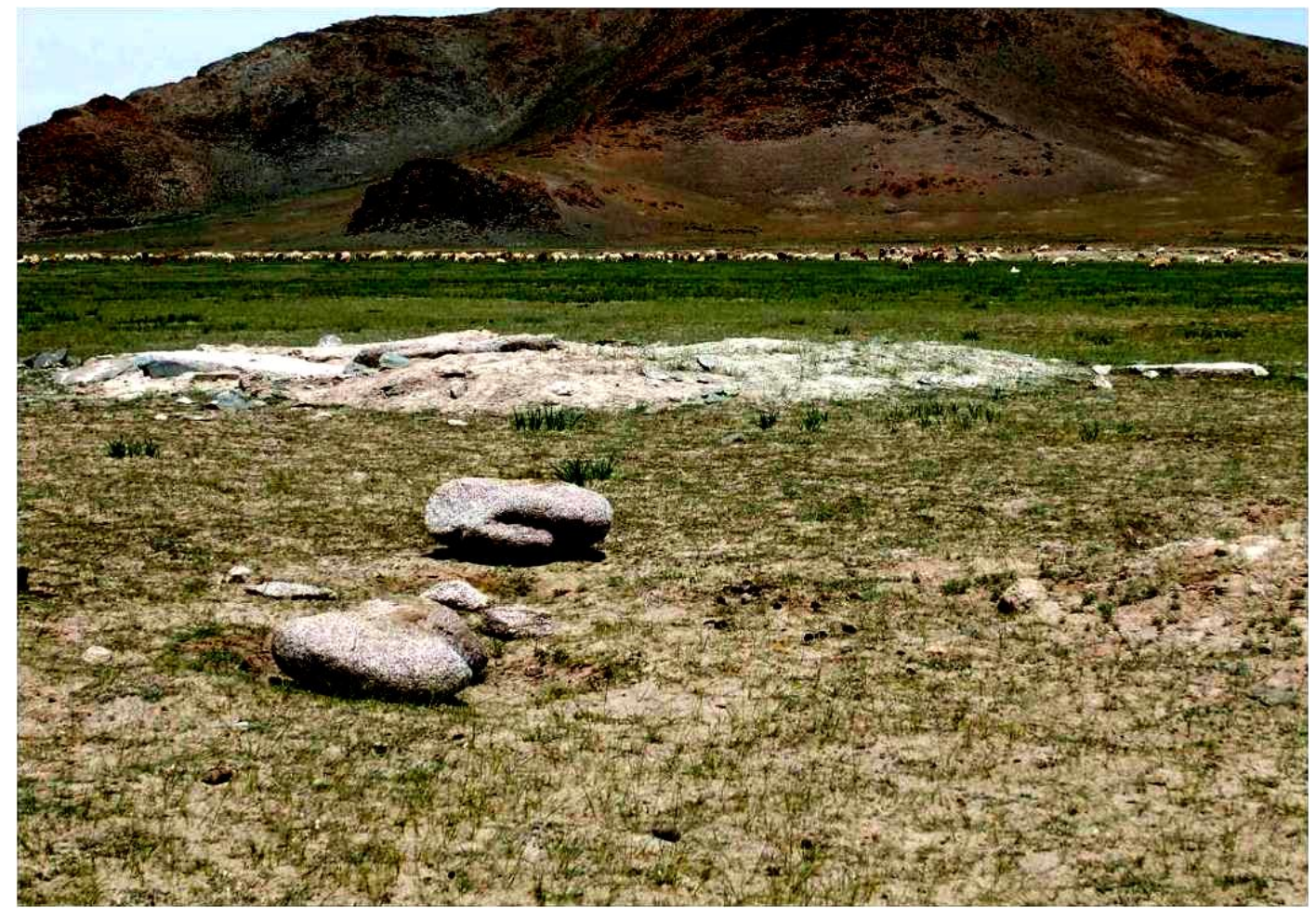

Olon Nuur'daki anıt mezarın genel görüntüsü

Anıt mezarı temizleme sürecinde çiçek tasvirli yeni iki levha ve anıt mezarın çatısı olarak kullanılan, merkezinde yuvarlak oyuk bulunan büyük levhanın yarısı tespit edilmiştir. Levhaların birisine 30 harften oluşan üç satırlık bir runik yazıt kazınmıştır.

Bundan başka mezar çatısının küçük bir parçasında da üç runik harften oluşan yazıt bulunmuştur. Söz konusu anıt mezardan doğuya doğru 850 metrelik bir balballar sırası uzanmaktadır. Anıt mezarın etrafında kiremit parçaları bulunmaktadır. Bu durum eskiden burada bir barkın olduğunu göstermektedir. 


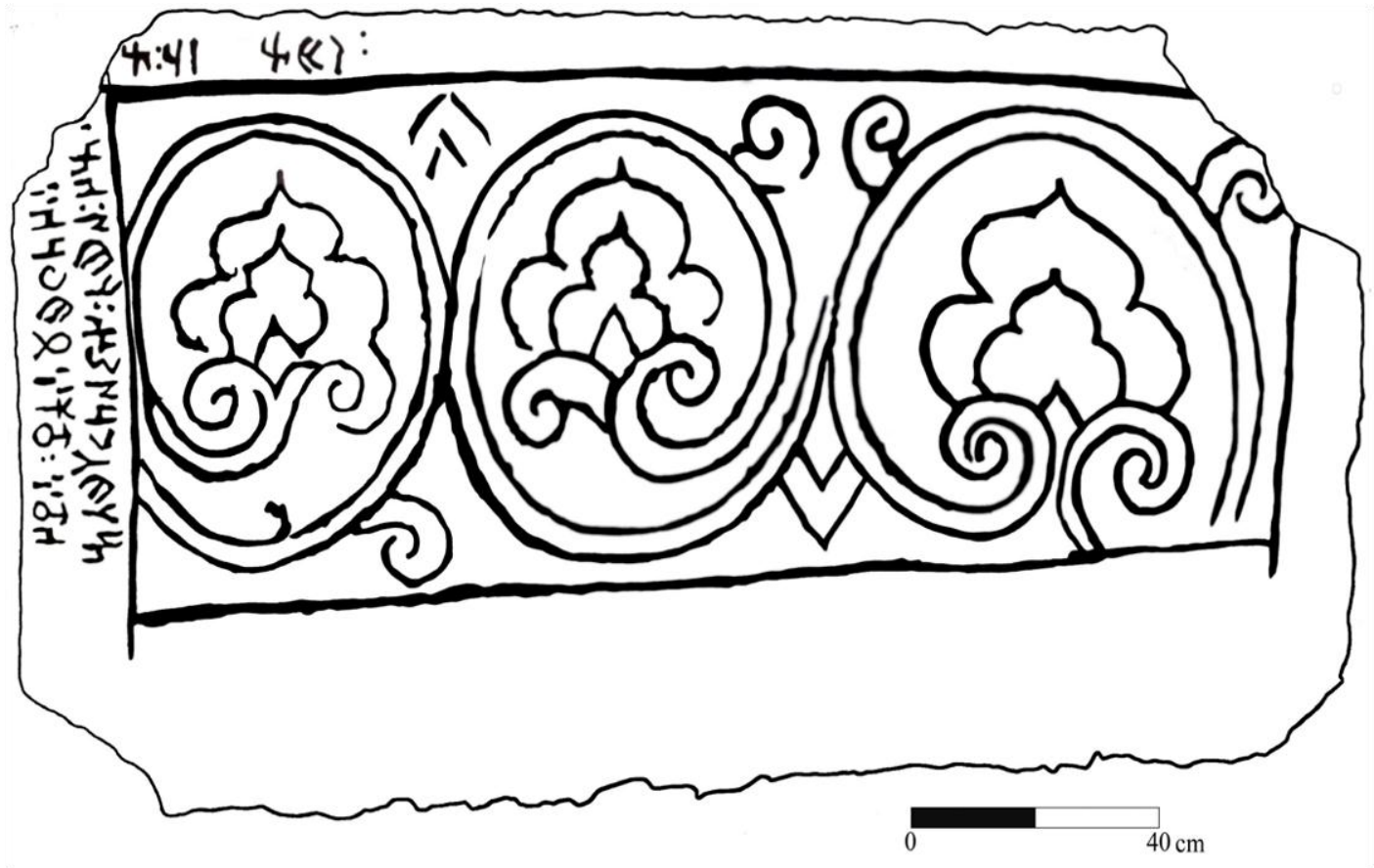

Olon Nuur'daki anit mezara ait levhalardan birinin üzerindeki Köktürk harfli yazıtın ve bezeklerin prorisovkası

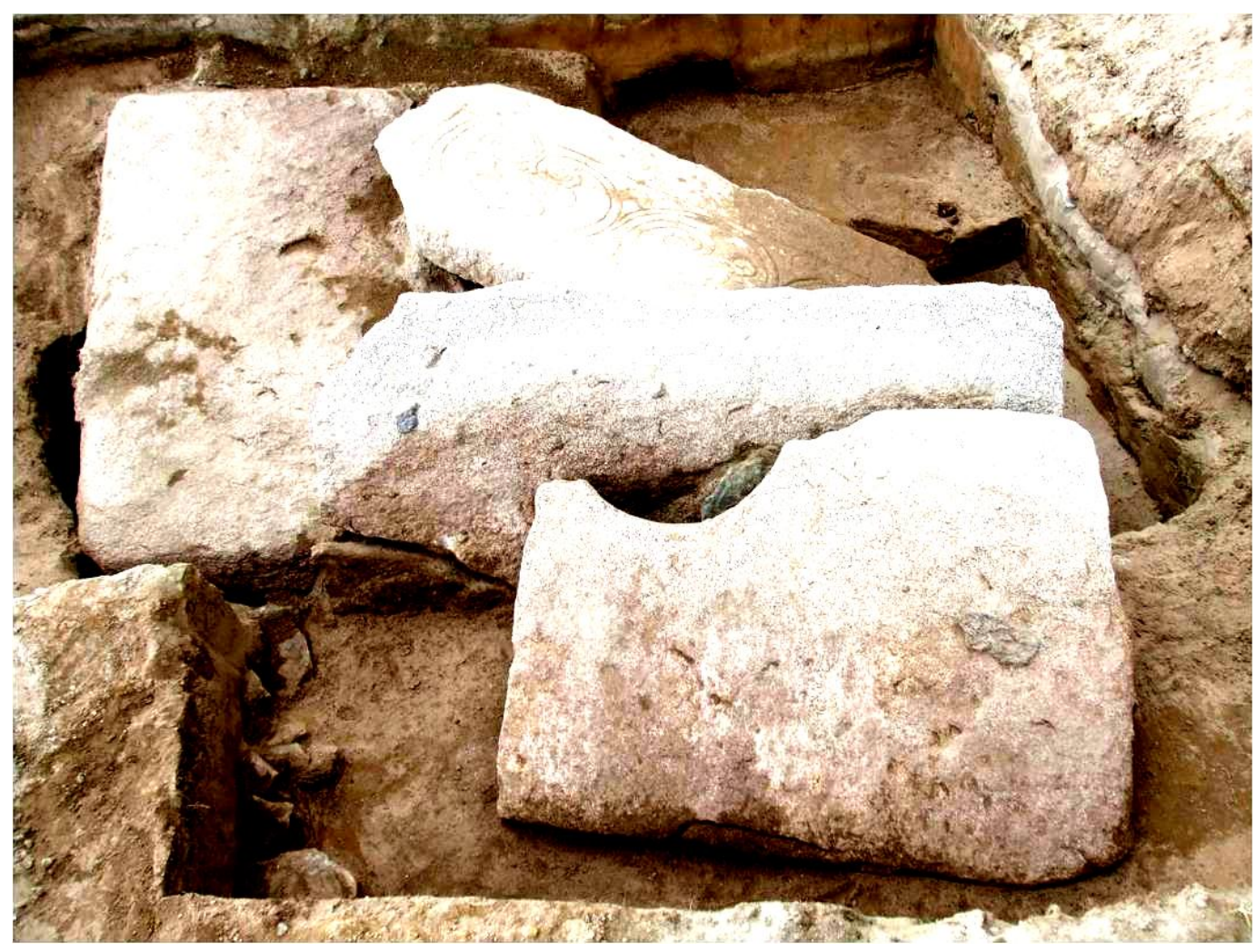

Olon Nuur'daki anıt mezardan ayrıntılı bir görüntü 
Söz konusu anıt mezar runik yazıtlı levhasının ve VII-VIII. asırlar anıt mezarlarında nadir görülen 'sarkofag' çatısının bulunmasıyla ilgi çekicidir. Burada belirtilmesi gereken nokta yazitlı levhalar sadece iki anıt mezarda (1- İh-Asgat anıt mezarında ve 2- İh-Hanuyn Nuur anıt mezarında) bulunurken, oyuklu çatı sadece Bilge Tonyukuk anıt külliyesinde yer almaktadır. Bunun için ele alınan anıt mezarı yukarıda söz edilen meşhur eski Türk kültür abidelerinin içinde değerlendirmek mümkündür.

Bölgede yaptığımız araştırmalar sırasında toprak üzerinde mezar duvarına ait iki bütün levha ile üçüncü levhanın parçası ve bağdaş kurup oturan bir insanı tasvir eden başsız taş baba ikiye parça hâlinde bulunmaktaydı.

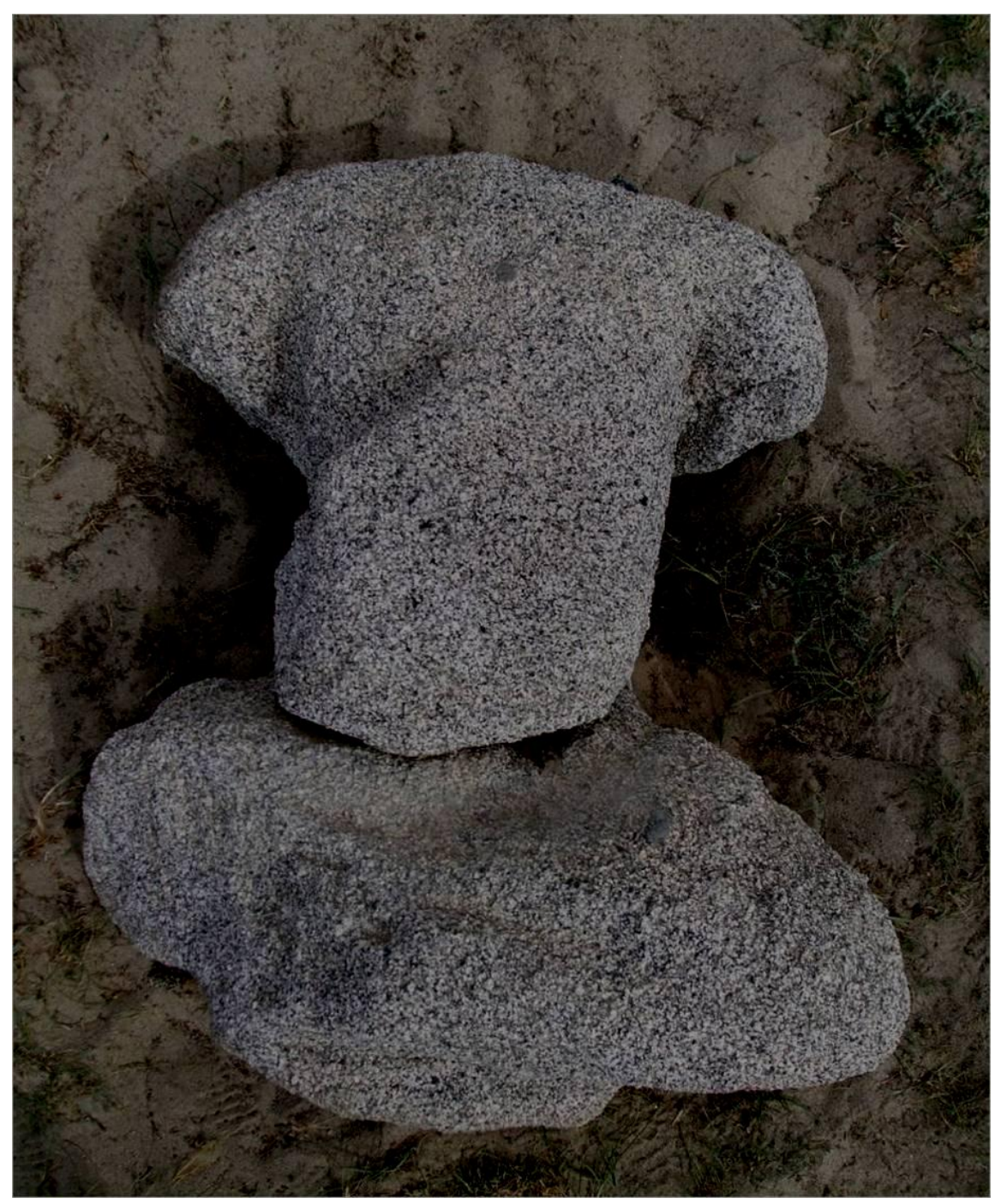

Olon Nuur'daki anıt mezarda bulunan insan heykelinin görüntüsü 


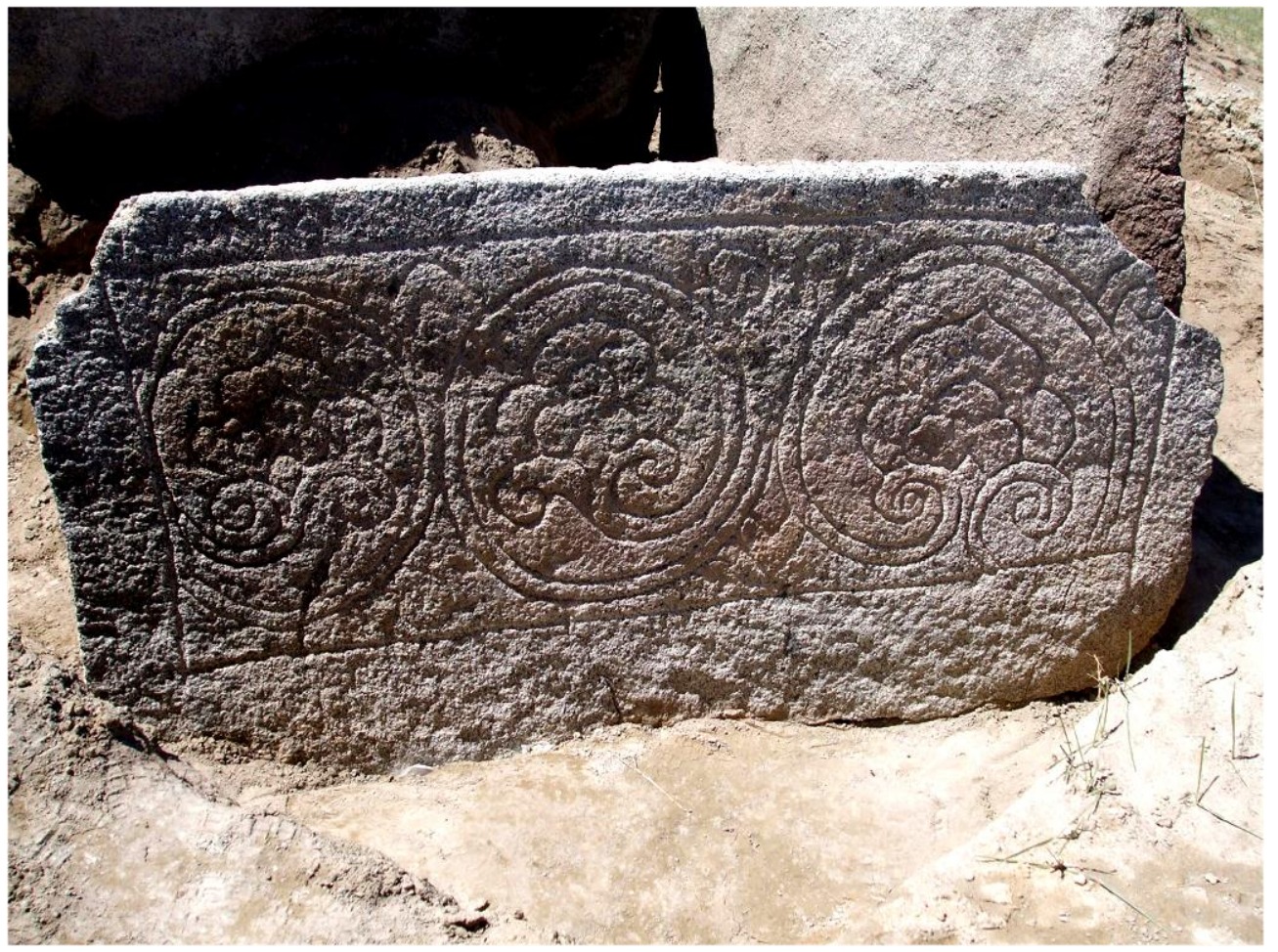

Olon Nuur'daki anıt mezara ait levhalardan birinin görüntüsü

Yazıtın metninden anıt mezarın kimin anısına dikildiği ve bu yerlerde nelerin yapıldığ belli olmuştur. Bu da Avrasya'nın eski göçebe topluluklarının anıt mezarlarını incelemede çok önemlidir.

Gelecekte bu anıt mezar üzerinde yeni kapsamlı ve sistemli kazıların yapılması, anıt mezarın ve mezara ait abidelerin restore edilmesi gerekmektedir. Bu sayede de Merkezî Asya’nın geniş bozkırlarını yurt edinen milletler hakkındaki bilgimiz artacaktır.

\section{2. Şiveet Dağı'ndaki Taş Yapı}

Arhangay Aymag'ta, Haşaat Sum topraklarında, meşhur Koşo Tsaydam abidelerinin yakınlarında bulunan Şiveet dağının tepesinde taş bir kurgana benzeyen yapının olduğu uzun zamandan beri bilinmekte idi. 2008 yılında söz konusu yapıda Moğol Devlet Üniversitesi Arkeoloji ve Antropoloji Ana Bilim Dalı araştırma heyeti çalışmış; yapı üzerinde kapsamlı bir kazı yapılmıştır. Yapı esas itibarıyla genişliği 70 metre, yüksekliği 5-7 metre olan büyük bir taş kurgandır. Bu kurgandaki taşlar eskiden yerli insanlar tarafından günlük hayat ihtiyaçlar için kullanıldığından kurganın ilk şekli küçülmüş ve ilk görünümünü kaybetmiştir.

Kazı sırasında üstteki taşlar alındıktan sonra kurganın merkezinde yer alan dörtgen şeklindeki iki katlı duvar yapı ortaya çıkartılmıştır. Bu yapının duvarları ince levhalardan oluşmaktadır. Bu yapı 36x36 metre boyutunda, 100-180 cm yüklekliğinde olup dört yöne 
bakmaktadır. İç duvar dış duvarından 30-60 cm. yüksektir. Hiçbir duvarında kapı bulunmamaktadır. Söz konusu yapının güney, batı kısımlarında ve batı duvarının birkaç yerinde güçlü ateş izi bulunmaktadır. İç alanda mezar çukurunun herhangi bir izine rastlanmamıştır. Yapı o dönemin çok kullanılan toprakları üstüne kurulmuştur.

Araştırmacılara göre ilk önce yapının iç duvarları, sonra dış duvarları yapılmıştır. İçinde ateş izlerinden başka, duvar boyunca ağaç direklerin kalıntıları da bulunmuştur. Duvarların yapılmasından sonra yapı taşla örtülerek bugünkü şekile gelmiştir.

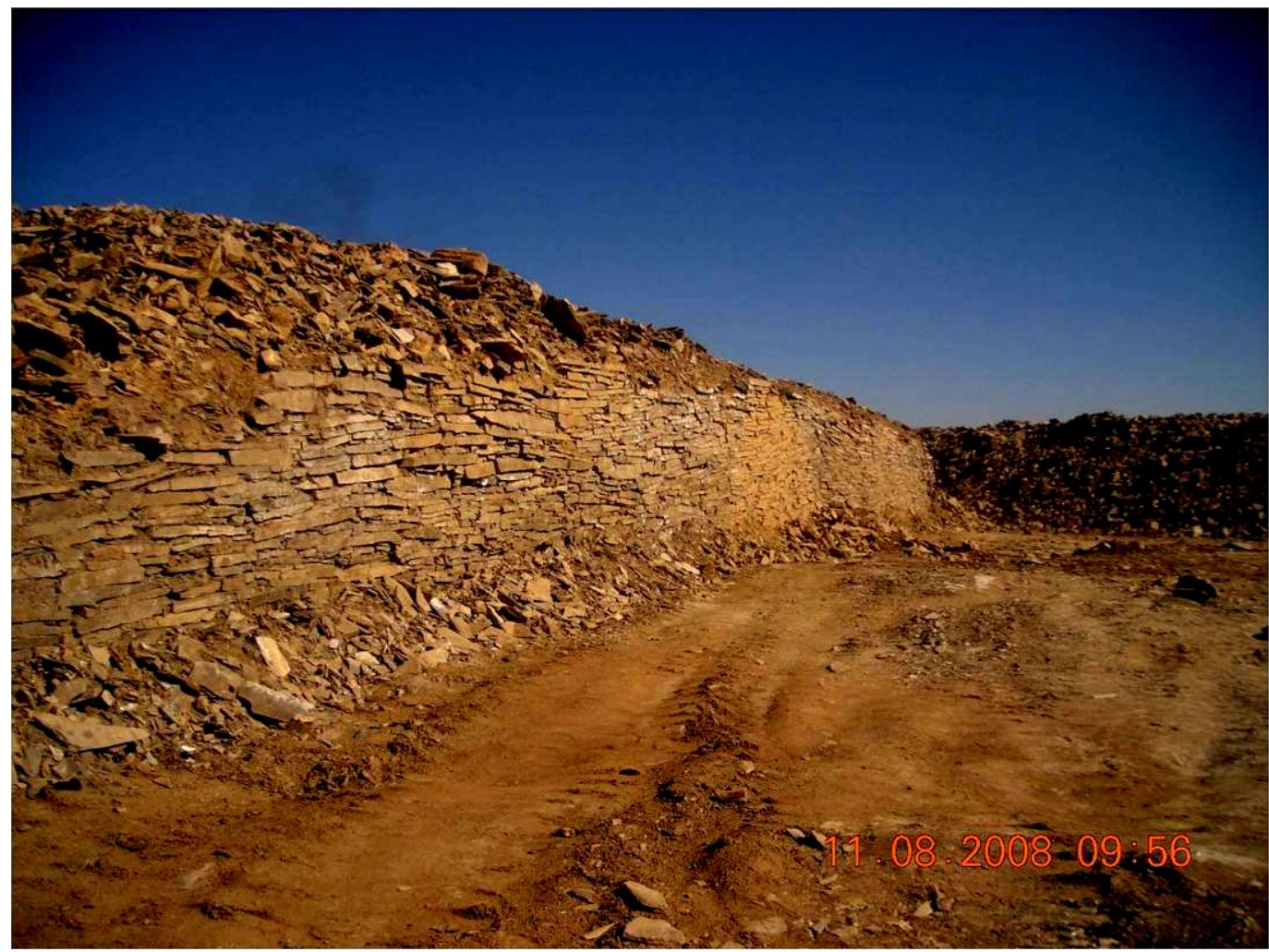

Şiveet'teki taş kurganin duvarlarından bir görüntü

Kazı sırasında batı duvarın dış kenarında, taş yığınlarının arasında bağdaş kurarak oturan ve sol elini sol dizinin üzerine koyan insan tasvirli güzel bir granit heykel bulunmuştur. Söz konusu taş babanın kafası güney duvarın doğu kısmında bulunmuştur. Heykelin yüksekliği 160 cm.dir. Biraz gülümseyen ve mongoloid tipte olan yüzü açık ve realist bir şekilde yapılmıştır. Bıyık ve sakalı yoktur. Eski Türk giysilerine mahsus olan özelliklere sahip geniş, uzun etekli kaftan giymiştir. Söz konusu kaftanın her tarafı çiçek tasvirleriyle kaplıdır. Belinde çok sayıda takımlı tokalarla ve salkımlarla süslü tipik eski Türk kemeri bulunmaktadır. Buna benzer büyük ustalıkla yapılan taş babalar eski Türk toplumunun ileri gelenlerine ait anıt mezarlarda bulunmaktadır. 


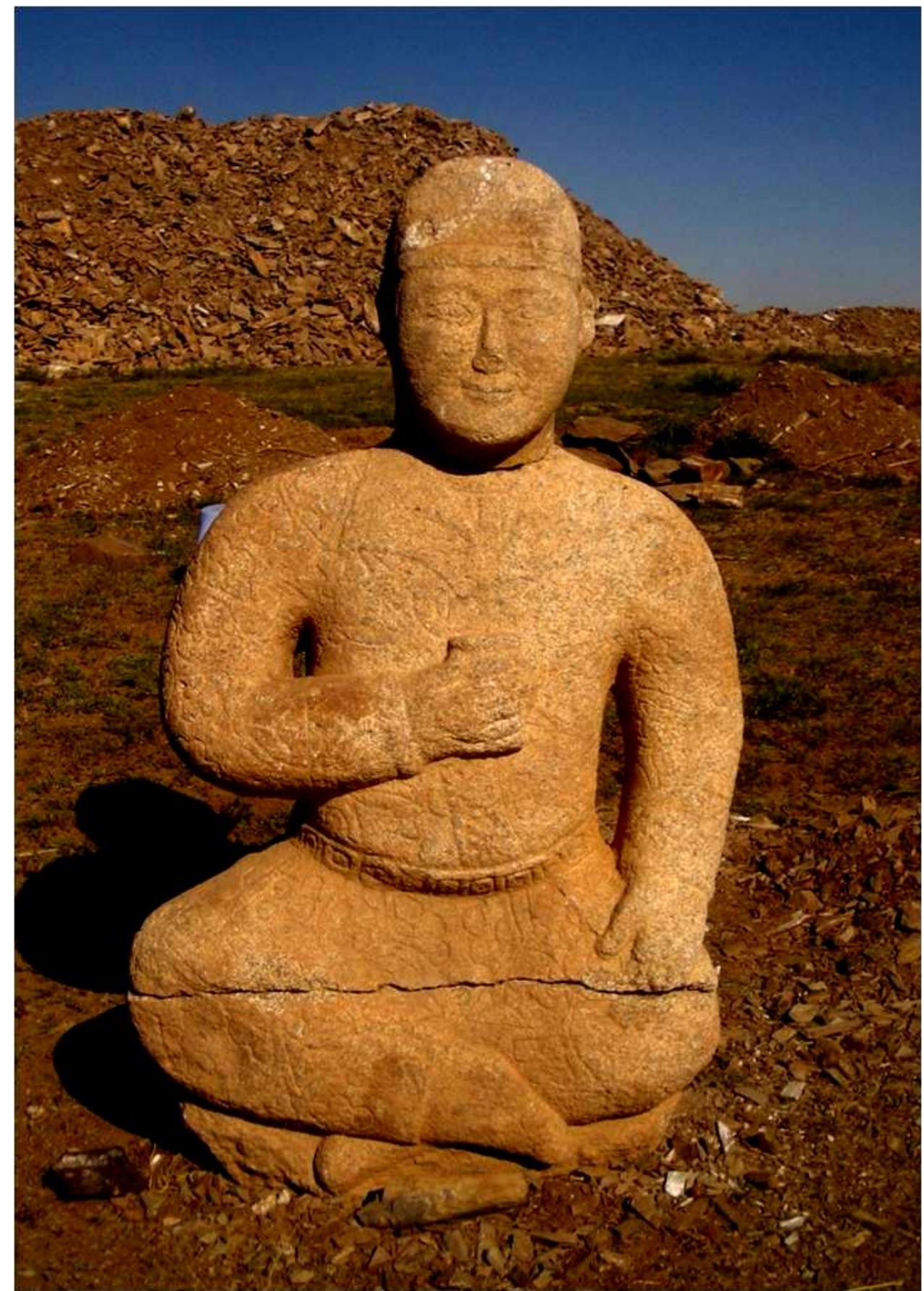

Şiveet'te bulunan insan heykelinin genel görüntüsü 


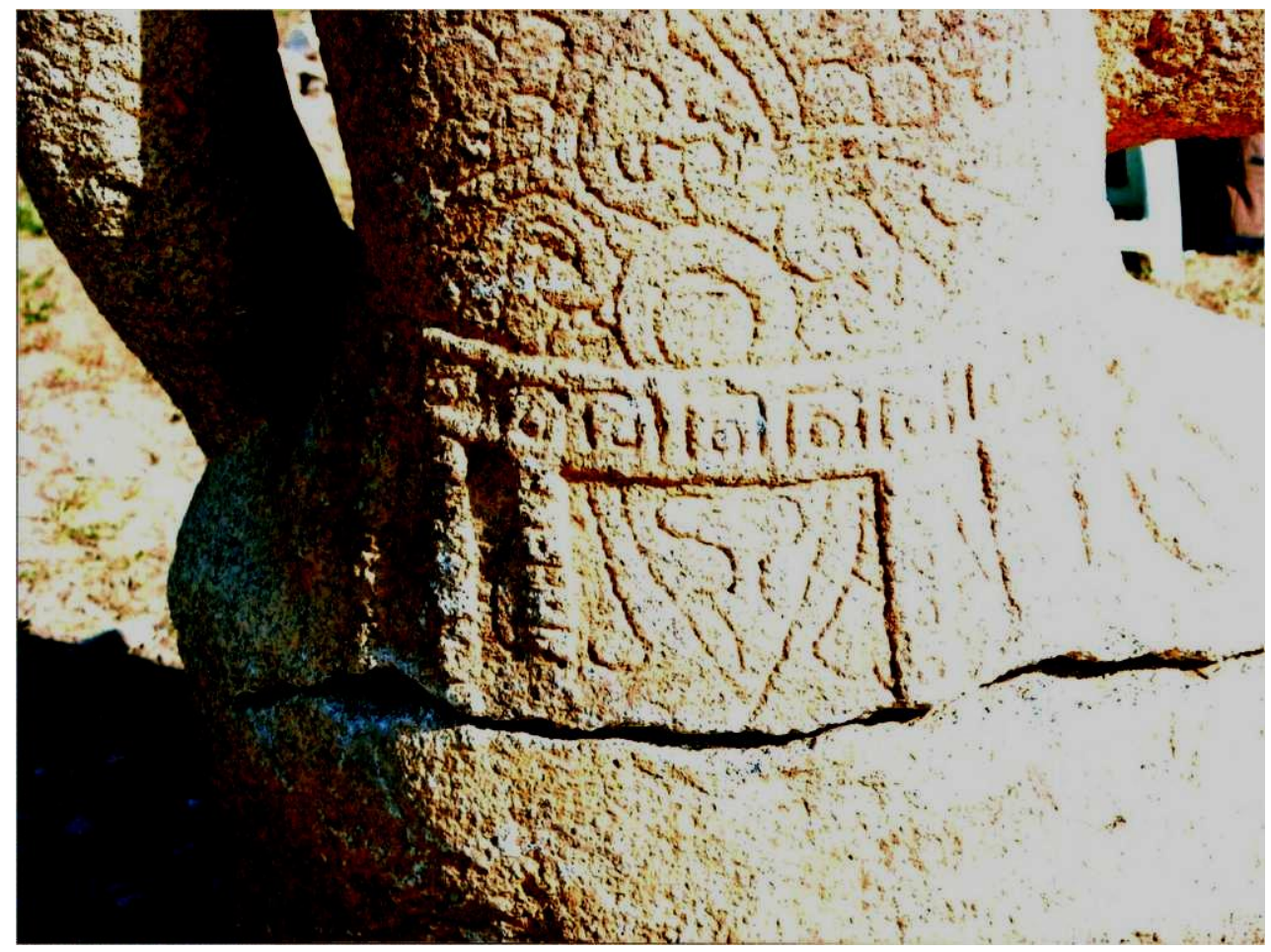

Şiveet'te bulunan insan heykelinin ayrıntılı bir görüntüsü

İncelemelerin sonucu gösterdiği gibi söz konusu anıt mezara benzer eserler ne Moğolistan'da ne de eski Türklerin yurt edindiği diğer yerlerde bulunmuştur. Bunun için bilim adamları bu yapının yakınlarında bulunan Köl Tigin ve Bilge Kağan mezar komleksleriyle ilişkili olabileceğini, hatta ikisinden birisinin toprak derinliklerine gizletilmiş yer altı mezarı olabileceğini düşünmektedirler.

\section{Nomgon'daki Eski Türk Anıtlar Grubu}

2007 yılında Uluslararası Göçebe Uygarlıklarını Araştırma Enstitüsü ile Moğolistan Millı̂ Müzesi tarafından oluşturulan bilimsel-araştırma inceleme grubu tarafından Arhangay Aymag, Haşaat Sum topraklarında bulunan İh Nomgon ve Baga Nomgon dağları arasındaki eski Türk anıtları incelenmiştir. Burada birbirinden 200 ile 1200 metre arasındaki uzaklıkta bulunan 8 ayrı anıttan oluşan eski Türk kültsel-mezar yapıları grubu bulunmuştur.

$\mathrm{Bu}$ anıtların hepsi bünyelerinde eski Türk anıt mezarlarına has özellikleri taşıdıkları gibi her anıt kendine ait orijinal özellikleri de barınmaktadır. Örneğin bazılarında kuşatma toprak tabyaların izi korunurken, bazıları sadece mezar duvarlarından oluşmaktadır. Diğer bir mezar ise mezar duvarları bulunmadığı hâlde koyun ve arslan heykellerini, balbalları içermektedir. Bazı anıt mezarlarda ise eskiden kurban kesme mabedinin olduğunu gösteren kiremit ve kerpiç kalıntıları bulunmaktadır.

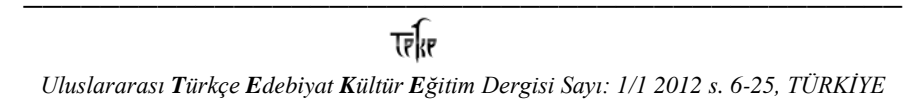




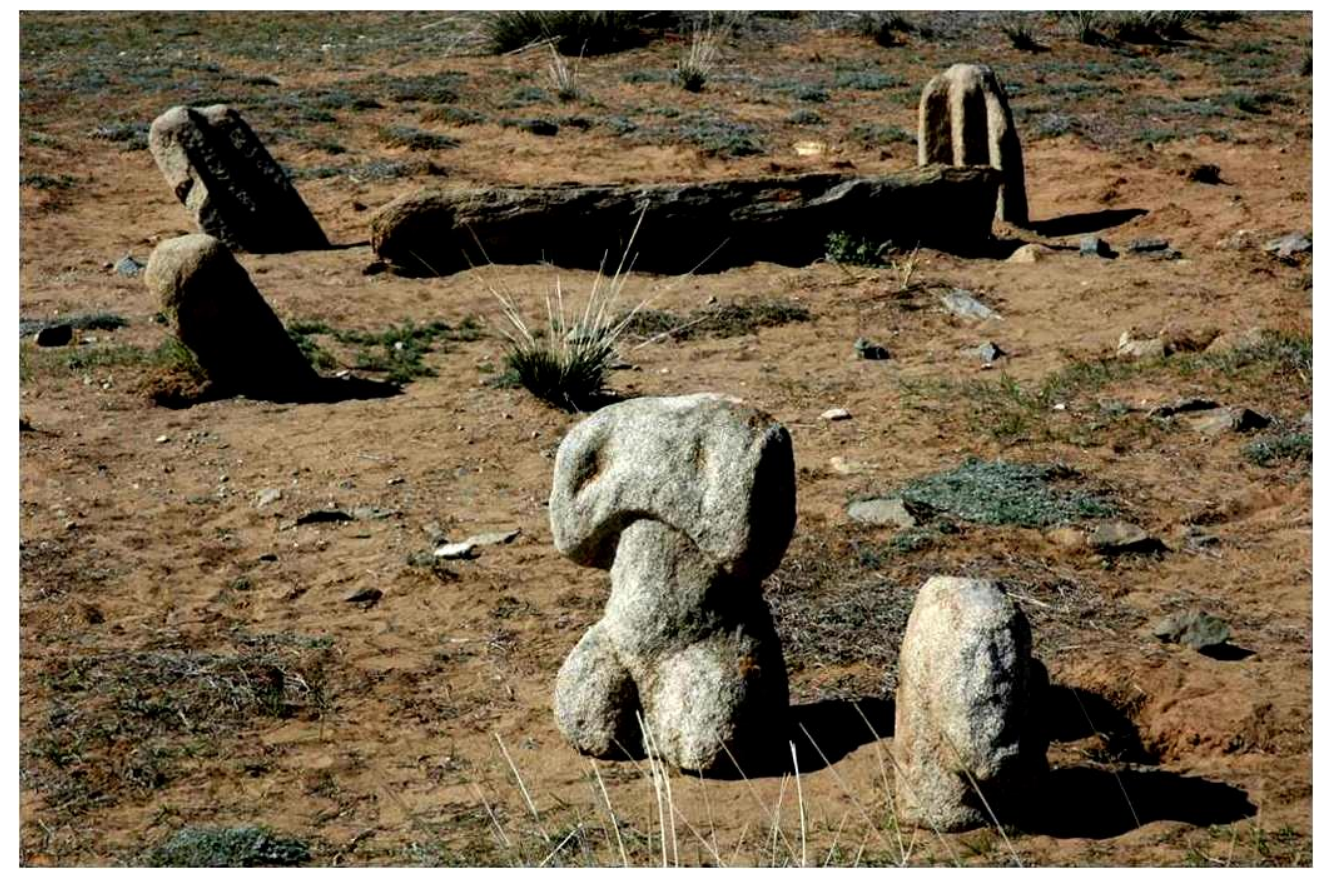

Nomgon'daki anıt mezarlardan birinin genel görüntüsü

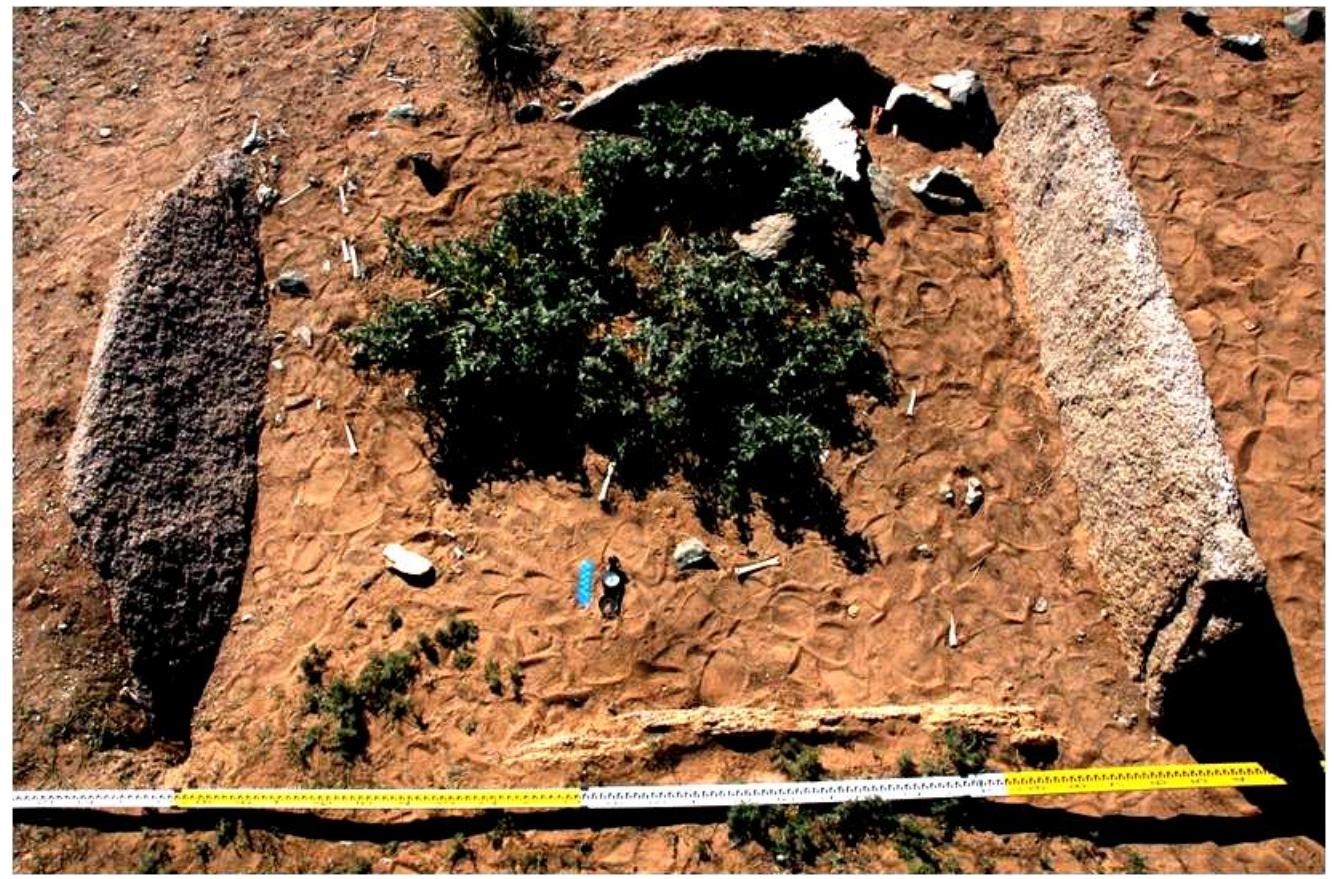

Nomgon'daki anıt mezarlardan birinin genel görüntüsü

İlgi çekici buluntuların içine 'Nomgın-I' anıt mezarında bulunan ve bilim adamlarına göre sunak taşı olan; merkezinde oyuk bulunan dörtgen şeklindeki taş da girmektedir. Bu tür taşlar önceleri sadece Bilge Kağan ve Köl Tigin mezar külliyelerinde bulunmaktaydı. Bu keşif de eski Türk anıt mezar komplekslerinde bulunan üçüncü örnektir. Bilim adamlarına göre böyle taşlar 
kağanlık ailesine ait birilerinin anıt mezarlarında sıradan dörtgen şeklindeki duvar yerine koyulmuştur.

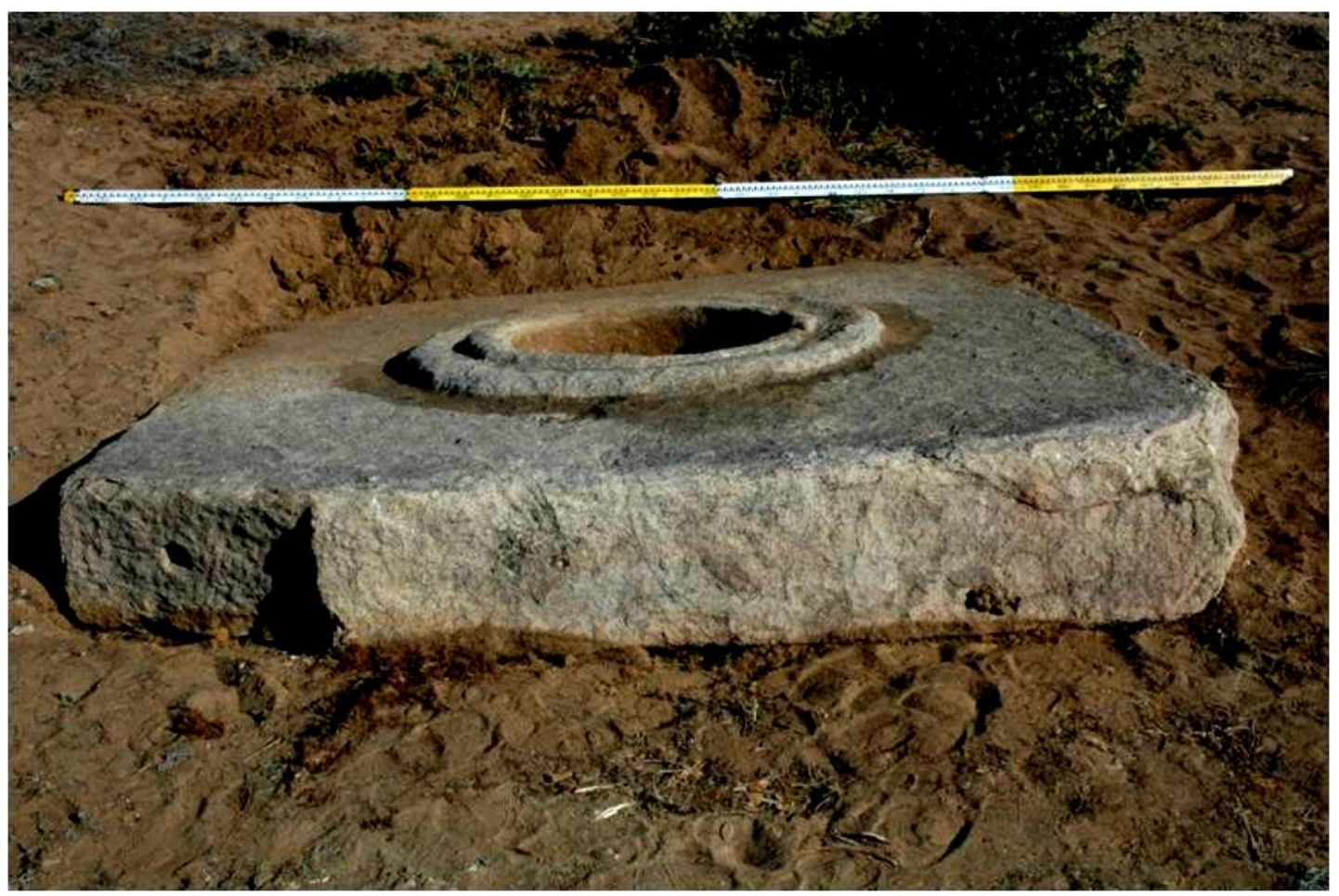

Nomgon'da bulunan sunak taşının genel görüntüsü

Mezar duvarlarının levhalarının bazılarında eşkenar dörtgen şeklindeki bezek bulunmaktadır. Bundan başka mezar duvarlarının kesiştiği yeri sağlamlaştırmak için kullanılan özel taş da ilgi çekicidir.

Burada toplam 11 taş baba bulunmuş ve hepsi de çok kötü durumdadır. Bunların 6's1 oturmuş vaziyette, 1 'i de ayakta durmuş şekildedir. Diğerleri ise çok tahribata uğradığı için duruşlarını tespit etmek mümkün değildir. Elinde büyük bir kap tutan ve 'Nomgon-VII' anıt mezarında bulunan oturmuş vaziyetteki taş baba çok ilgi çekicidir. Böyle taş babalar genellikle toplumun ileri gelenlerine, soylu ailelerine ait ferdlerin anısına yapılmış büyük mezar komplekslerinde yer almaktadır. Bundan başka koç ve arslan gibi hayvanların heykelleri de bu görüşü desteklemektedir. 


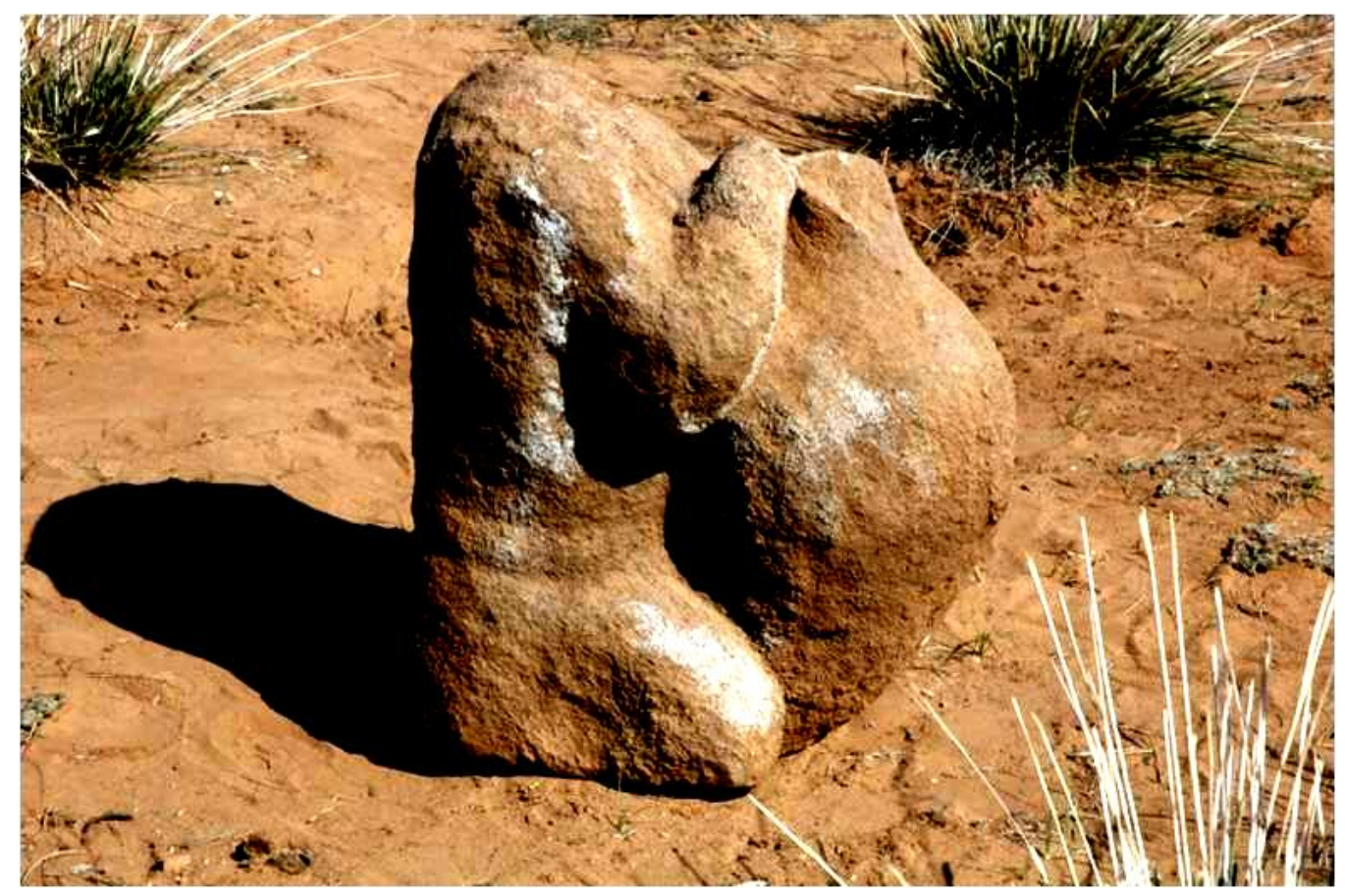

Nomgon'da bulunan insan heykellerinden birinin görüntüsü

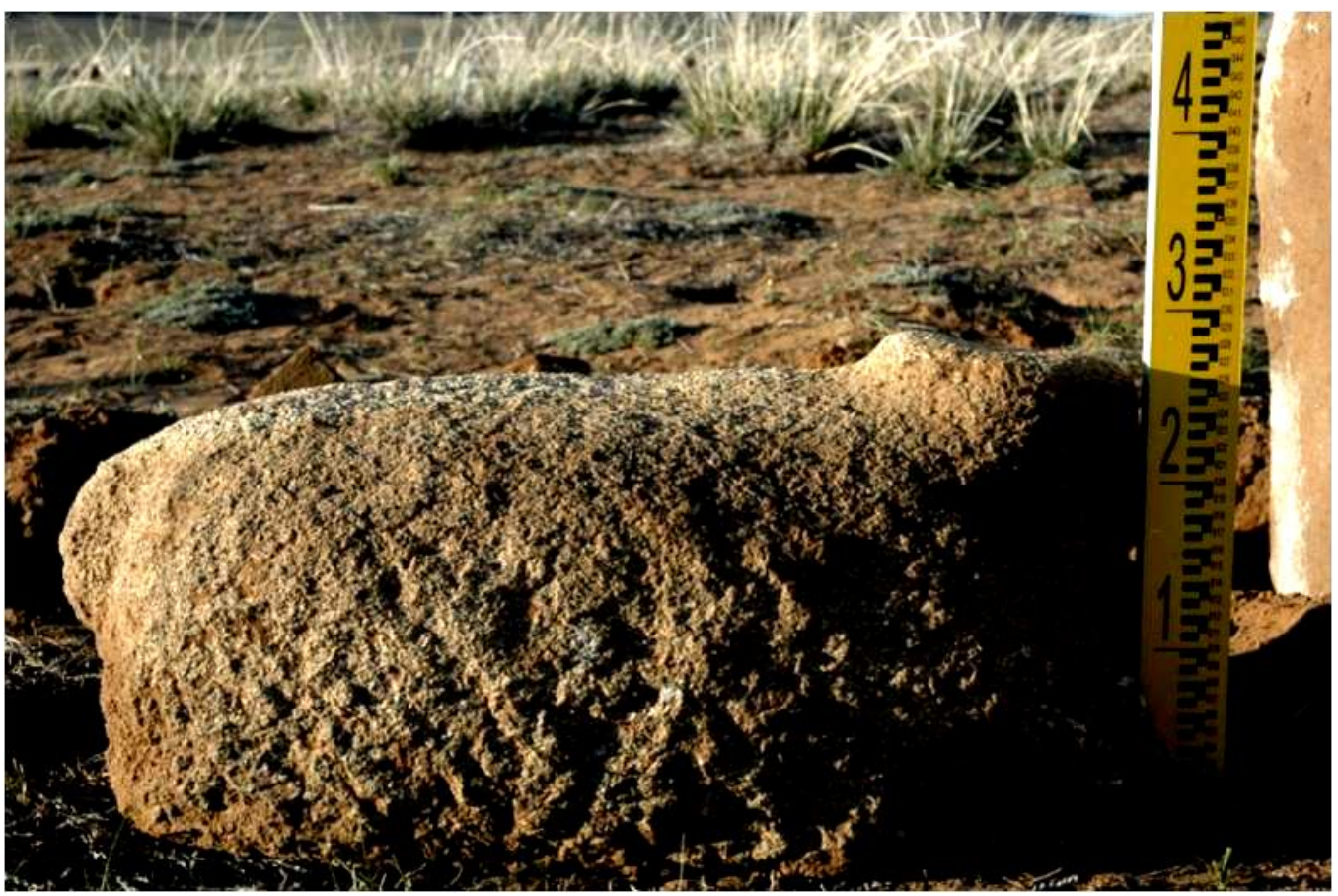

Nomgon'da bulunan hayvan heykellerinden birinin görüntüsü

Üç anıt mezarda balbal dizisi bulunmaktadır. Balbal dizilerinin uzunluğu, 200-300 metre olup, balbal sayısı 10-42 arasında değişmektedir. 'Nomgon-I' anıt mezarındaki 12. balbalda kağanlık boyunu sembolize eden dağ keçisi damgası bulunmaktadır. 
Yazıtların bulunmamasına rağmen, toprak tabyanın, anıt tapınağın kalıntılarının, değişik heykellerin, bezekli duvar levhalarının bulunması ve taş babaların vaziyetleri Nomgon arazisindeki söz konusu anıt mezarların VIII. asırdaki Eski Türk ileri gelenlerine ait büyük külliye olduğunu göstermektedir.

\section{Uygur Soylularının Yeraltı Makbereli Mezarı}

Arhangay Aymag, Hotont Sum topraklarındaki Hulhiyn Am, Hundiiyn Hooloy ve Uvur Havtslın Am arazilerinde uzun zamandan beri bilim adamları tarafindan incelenmeyen değişik yapıdaki anıt mezarlar grubu bulunmaktadır. 1933 yılında D. D. Bukiniç, Hundiiyn Hooloy grubunu bularak bir ya da iki anıt mezarda kazı yapmıştır.

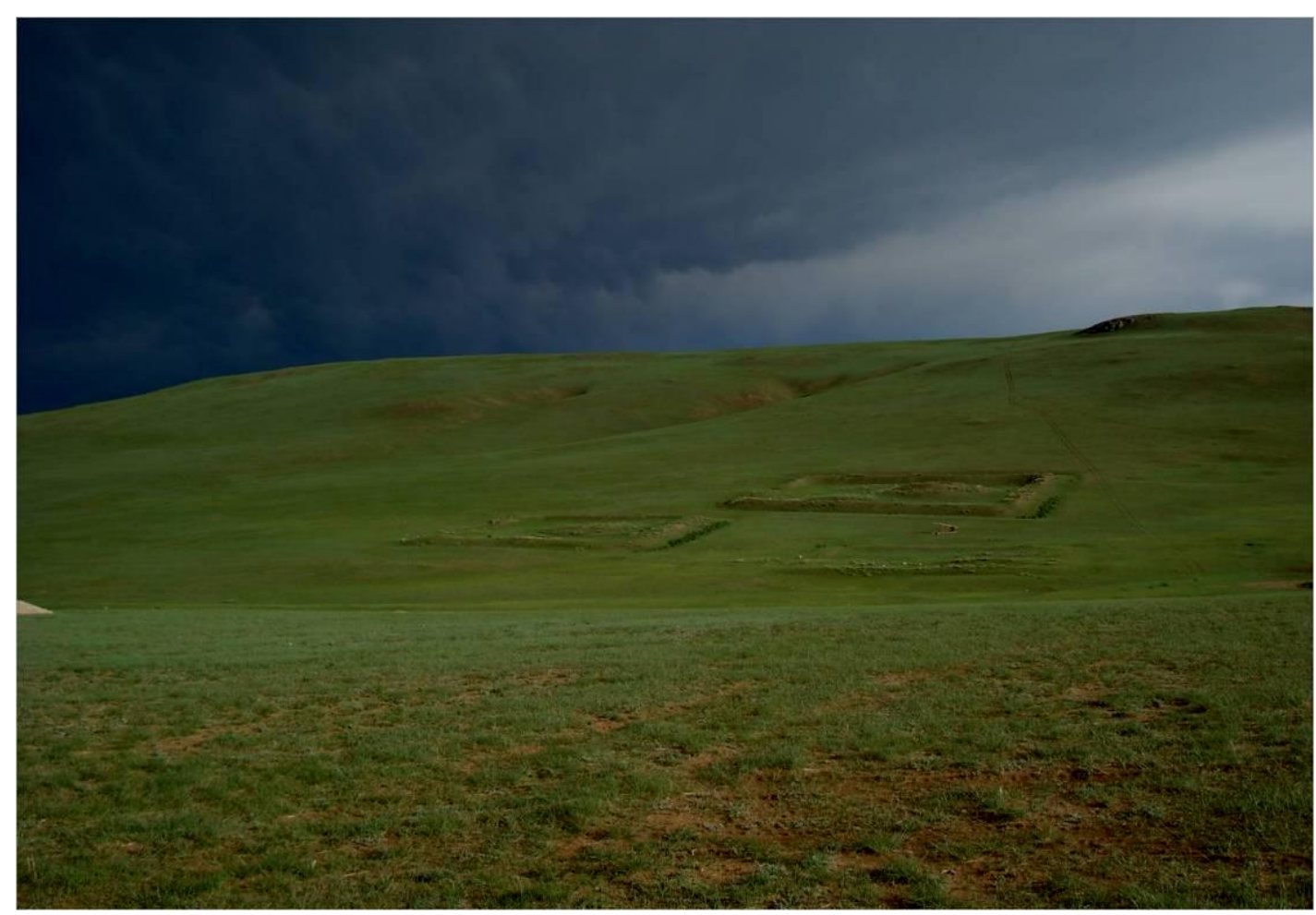

Anıt mezarların kazı öncesi görüntüleri

Sonuçları Arkeoloji Enstitüsü arşivinde korunmaktadır. 1998 yılında söz konusu anıt mezarlar Moğol arkeologları tarafından tespit edilmiş ve kayıt altına alınmıştır. Bugünlerde Hotont Sum topraklarında 40 anıt mezar bellidir. Yerli halk bunlara 'dürvuljin'('dörtgenler') demektedir. 2006-2008 yıllarında Moğol ve Çin arkeologları birlikte 6 anıt mezarda ilk defa kazı yapmışlardır. Arkeolojik çalışma sonucunda buranın soylu ailelerden bir ferde ait (dörtgen şekildeki toprak tabya ve arklarla kuşatılmış üst kısmı taşlarla kaplanmış) yeraltı kubbe makbereli mezarı olduğu anlaşılmıştır. Toprak tabyanın güney doğu yönünde kap1 bulunmaktadır. Bu yapıların ölçüsü farklıdır: 21x21 ile 34x51 metreye arasında değişmektedir. 


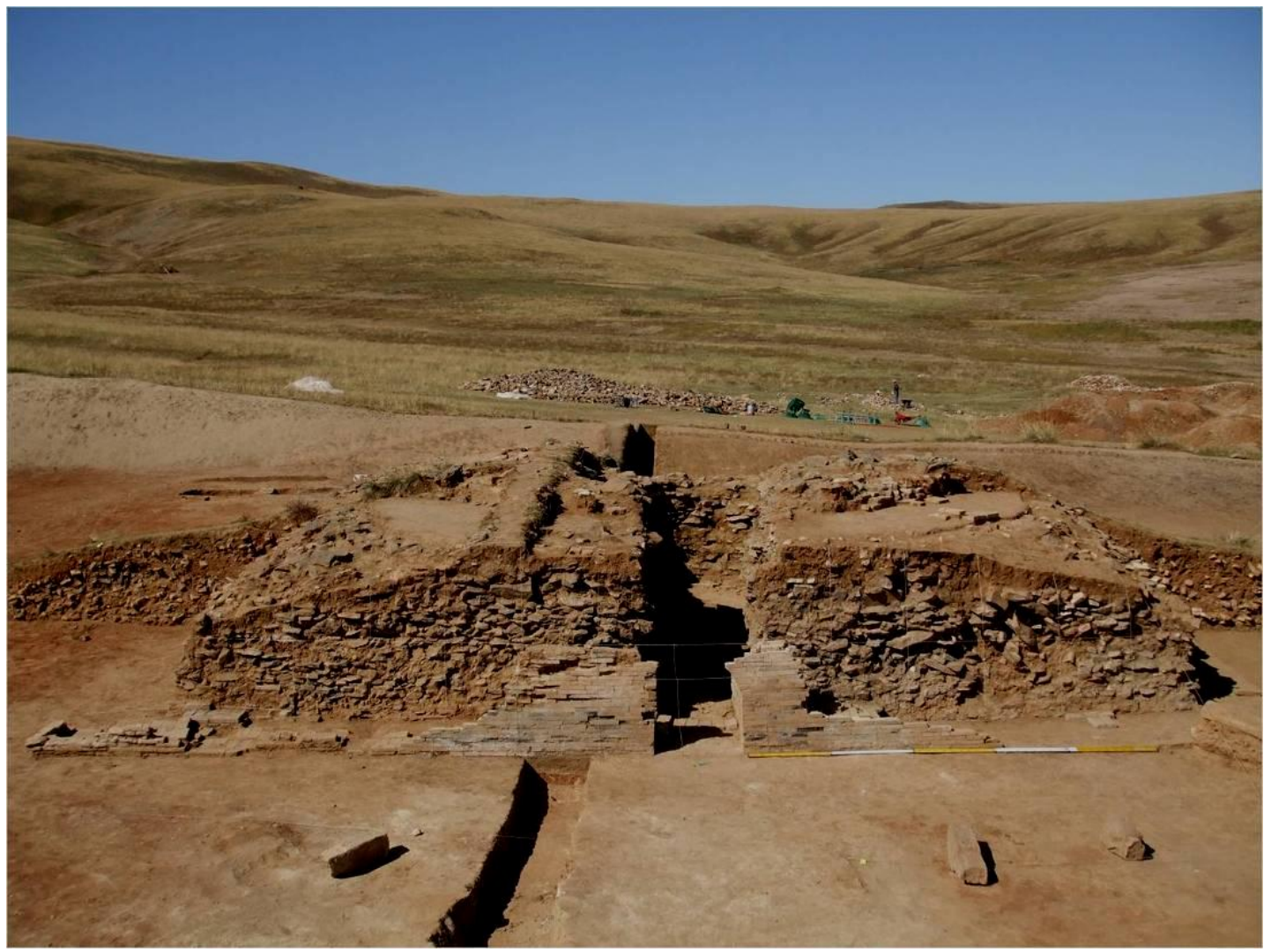

Anıt mezarlardan birinin kazı sonrasina ait bir görüntüsü

Boz üy / çadır şeklindeki yeraltı makbere-hücreler tuğladan yapılmıştır. En büyük hücrenin boyutu, genişliği 4.3. metre, yüksekliği 2.3 metredir. Defin edilen kişi sayısı da değişiktir. Bir kişiden beş kişiye kadar gömülmüştür. Her kişi bir hücreye gömülmüştür. Bununla birlikte değişik şekilde, yan yana gömme de bulunmaktadır. Bu tür gömme birlikte gömülen çok sayıdaki eşya, envanterleri yağmacılardan koruma amacıyla uygulanmış olabilir. Toprak tabya içinde mezar makberelerden başka havan şekildeki ritüel fonksyonlu yapılar bulunmaktadır.

Ne yazık ki, incelenen anıt mezarların hepsi eskiden yağmalanmış, değerli eşyaların tamamı kaybolmuştur. Kazı sırasında kerpiç, çatı kiremitleri, kiremit diskleri, hayvan bezekli mimari süsü, iyi korunmuş çiçek bezekli duvar freski, tipik uygur bezekli kap parçaları gibi yapı gereçleri, runik yazıtlı yay kanadı, deri etik, bez parçaları şeklindeki giysi kalıntıları, değişik metal eşyalar, kişi ve hayvan kemik parçaları gibi değişik nesneler bulunmuştur.

Söz konusu yapılar şekil ve yapı bakımından Çin'in kuzeyinde bulunan ve incelenen anıt mezarlara benzemekte, özellikle Kidan ileri gelenlerine ait yer altı mezar makberelerine benzemektedir. Ancak, yapı gereçleri Tan karakterlidir. Seramikler Moğolistan ve Tıva Uygur mezar anıtlarında bulunan seramiklere benzemektedir.

\section{Tर्शि}

Uluslararası Türkçe Edebiyat Kültür Eğitim Dergisi Sayl: 1/1 2012 s. 6-25, TÜRKIYE

International Journal of Turkish Literature Culture Education Volume 1/1 2012 p. 6-25, TURKEY 


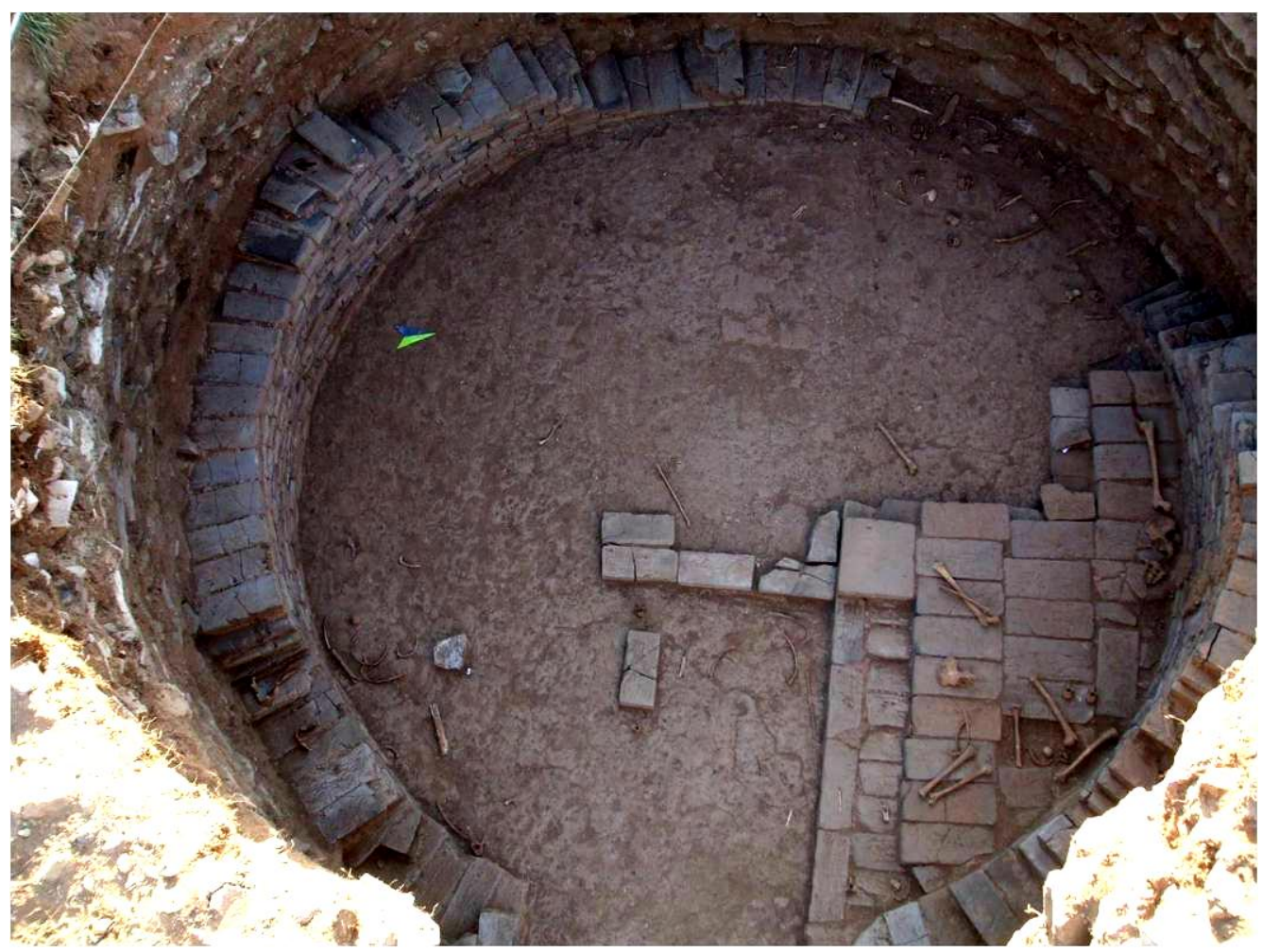

Anıt mezarlardan birinin iç bölümüne ait bir görüntüsü

Özellikle, bazı mimari ayrıntılar 2007-2008 yıllarında Rus bilim adamları tarafindan kazılan Tıva'daki Por-Bajın Uygur ada kalesinde bulunanlarla tamamıyla uyuşmaktadır. Bir anıt mezarda runik yazıtlı yay kanadının bulunması bu anıt mezarların Uygurlarla ola ilişsisini göstermektedir. Çünkü, Uygurlar da bu yazıyı kullanmışlardır. Böylece, Hotoht Somoondaki bugüne kadar bilinmeyen kubbe şeklindeki mezarlıklar Merkezî Asya göçebelerinin güzel eserleri olmaktadır. Bunun için, bu yapılar üzerindeki ilk çalışmalar orta asırlarda Moğolistan'da oturan halkların maddi ve manevi kültürünün çözülmeyen meselelerinin incelenmesinde katkıda bulunacağı kesindir. 


\section{Kara Balgasun'da Yeni Araştırmalar}

Uygur devletinin başkenti Kara Balgasun'un kalıntısı XIX. asrın sonunda bulunmuştur. 1891 yılında Akademik V. V. Radloff'un başında bulunduğu Orhon Ekspedisyonu ilk defa şehrin topografik yapısını çizmiştir. Ancak, 1948 yılında Prof. S. V. Kiselev başkanlığındaki Moğol-Sovyet Heyeti tarafından yapılan ön arkeolojik kazıdan başka kapsamlı bir kazı yapılmamıştır.

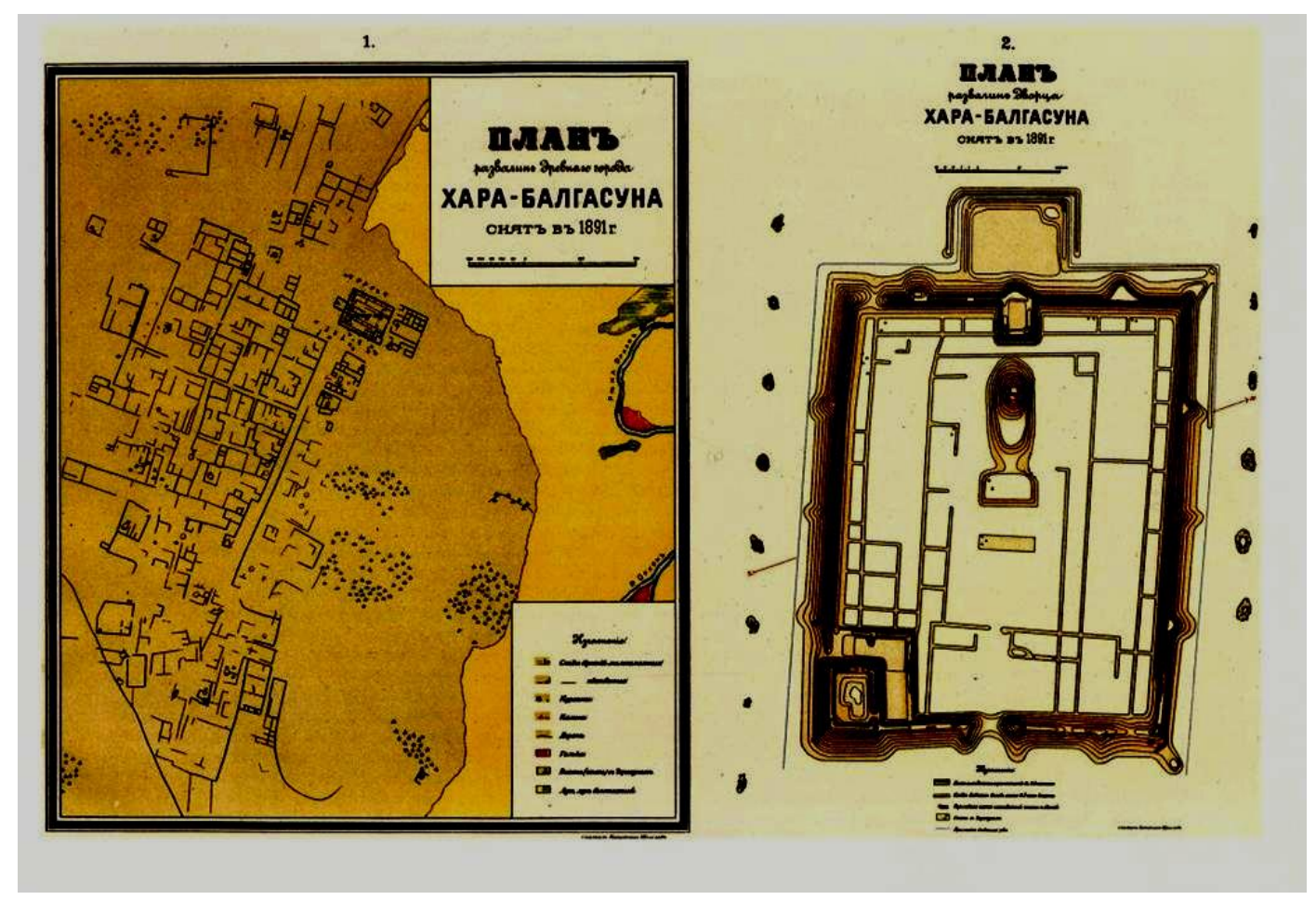

Orhon Ekspedisyonu tarafindan yapllan topografik harita ve plan

Orhon vadisi arkeolojik eserlerini birkaç yıldır incelemekte olan Moğol-Alman Heyeti'nin sürdürdükleri proje kapsamında 2006 yılından beri söz konusu şehri incelemek amaciyla kapsamlı çalışmalar yapılmaktadır. Bu proje ekibinin öncelikli görevi ileri teknoloji araçları vasıtasıyla şehrin bütün alanlarının planını çıkartmaktı. Bu amaç doğrultusunda 2007 yılında, proje üyeleri helikopterle şehir kalıntısı üzerinde uçuş yaparak lazer tarayıcısı araçlarıyla (ALS = Airborne Laserscanning) şehrin bütün alanlarının planını çıkarmaya çalışmıştır. Bu çalışma sırasında 43 kilometre kare alanda uçuş yapılmış, 548 yerin ölçümü yapılmıştır. Bunların sonucunda da 0.25 metrelik çözünürlüklü üç boyutlu (DTM = Digital Terrain Model) modeli yapılmıştır. Eski çalışmalara göre Kara Balgasun'un alanı 25 kilometre kare iken havadan çekilen fotograflar sayesinde 32 kilometre kareden az olmadığg anlaşılmıştır. 


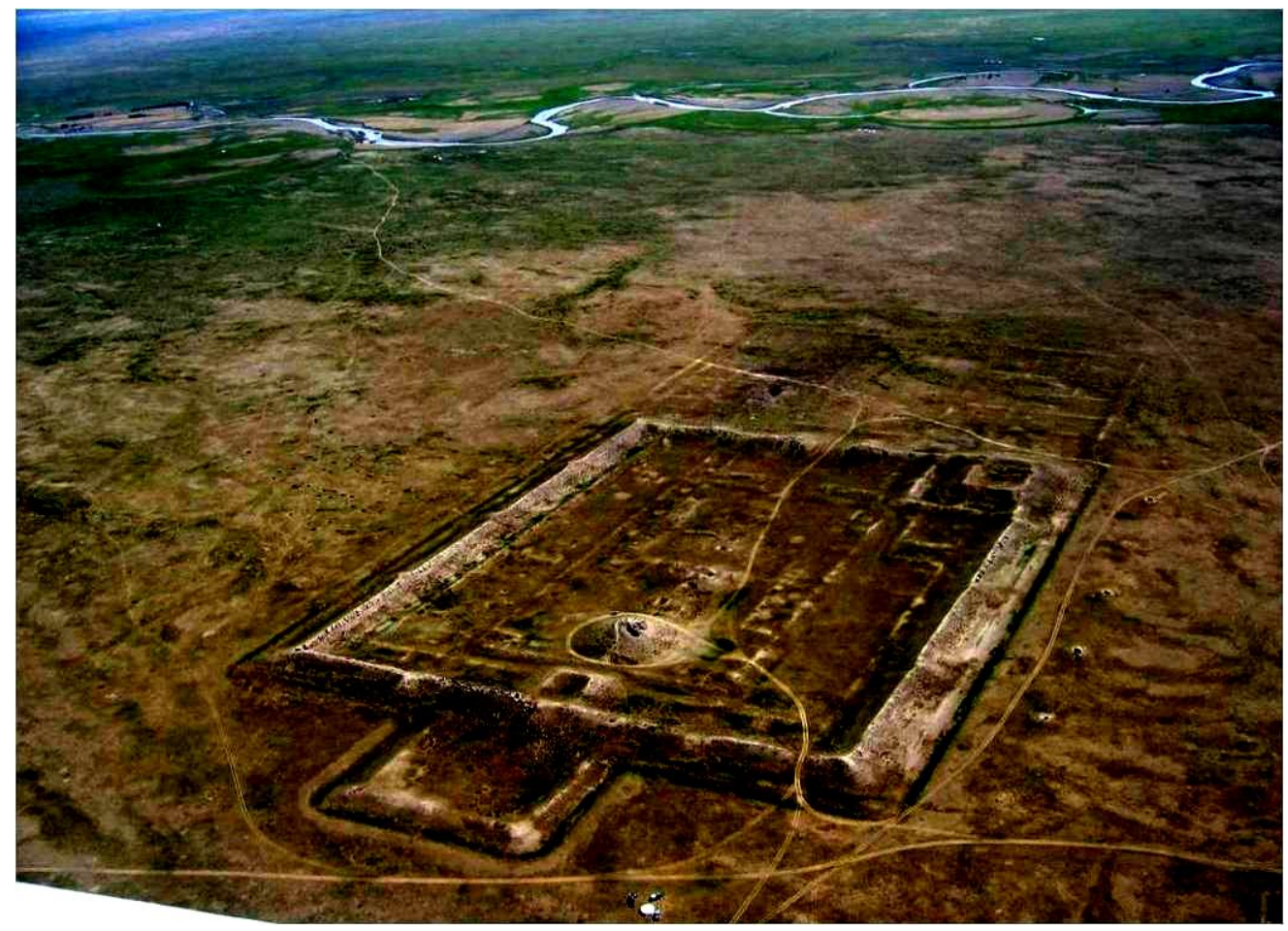

Karabalgasun'un genel görüntüsü

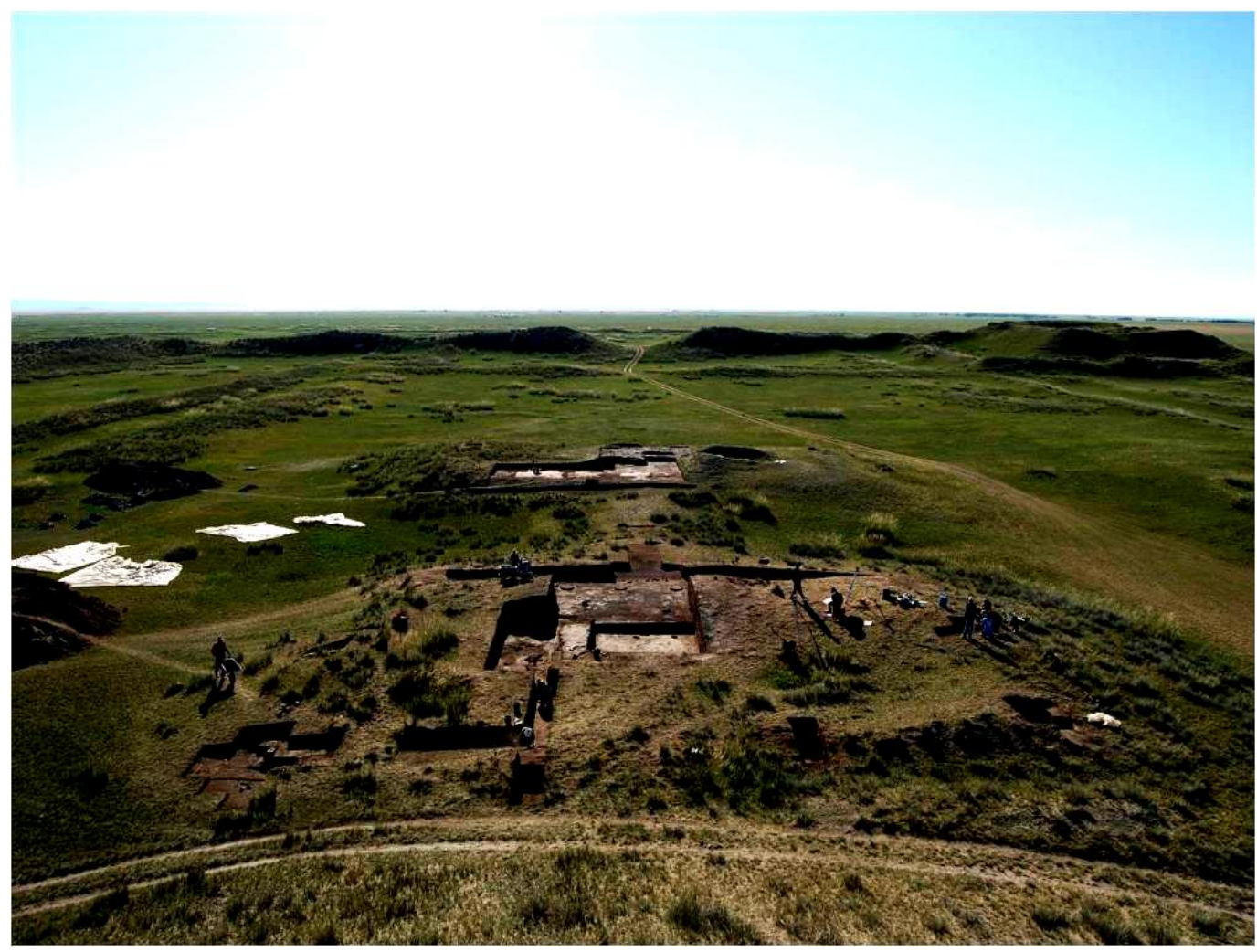

Karabalgasun'daki kazı bölgelerinden genel bir görüntü 
Proje ekibi aynı zamanda ilk kazı çalışmalarına da girişmiştir. Kazı yeri olarak önce 1948 yılında S. V. Kiselev önderliğindeki ekspedisyonun kazı yaptığı yer seçilmiştir. Kale duvarlarının içindeki büyük pagodanın doğu tarafında bulunan küçük bir yapı kalıntısında ve büyük tepede yapılan eski kazı kalıntıları temizlenmiştir. Kazı sonucunda içinde ateş izi ile dörtgen şeklindeki ağaç duvar bulunan yapının kalıntısı ortaya çıkarılmıştır. Bu yapının kullanım fonksoyonu belli olmamasına rağmen buluntuların özelliklerine göre Tan (VIII-IX asırlar) dönemine ait olduğu kesindir. Bundan başka kağanlık sarayının güneyindeki küçük tepecikte, yani üç dilde yazılmış meşhur yazıtın bulunduğu yerde de kazı işlemi başlatılmıştır. Burada büyük bir kil duvarın olduğu anlaşılmıştır. Burada Tan devrine ait yapı gereçleri, Uygur bezekli seramik parçaları ve söz konusu yapının Kidan devrinde de kullanıldığını gösteren Kidan seramikleri bulunmuştur. Bu evin yakınlarında daha sonraki dönemlere ait bir anıt mezar da bulunmuştur. Gömme şekli, ortaya çıkarılan aletler söz konusu anıt mezarın orta asır Moğollarına ait olduğunu göstermektedir. Bundan hareketle söz konusu yapının orta asırlara kadar terk edildiği düşünülebilir.

Ortak projenin işe başlaması, ilk önce şehir kalıntısının yüksek teknoloji araçlarıyla plana alınması bilim adamlarına geniş ölçülü topografik-arkeolojik belgelemesini vererek Kara Balgasun'un incelenmesi açısından geniş olanaklar sağlamıştır. Aynı zamanda bu çalışmalar Moğolistan'da bu doğrultuda esaslı araştırmaların yapılmasına olanak sağlamıştır.

\section{Jargalant-Hayrhan Dağlarındaki Kaya Mezarı}

Kobd Aymag'daki Manhan ve Çandman Sumları arasında yer alan Jargalant-Hayrhan dağındaki bu ilginç mezarı arkeologlar yerli halktan öğrenmiştir.

2008 yılında bu arazide Moğolistan Bilimler Akademisi Arkeoloji Enstitüsü araştırma heyeti çalışmalar yapmıştır.

Jargalant-Hayrhan'ın bir vadisinde Nuht Had adlı bir küçük dağ vardır. Bu dağın tepesinde taşlar arasında dikey girişli küçük bir mağar bulunmaktadır. Bu mağarada kadim halklar merhumları gömmüşlerdir. Mağara yerli halklar tarafından biraz tahribata uğratılmış, ancak eşyaların tamamı korunmuştur. Bu mağara 20-25 yaşındaki bir erkeğin defin yeridir. Ceset sırt üstü uzatılmış şekilde kafası kuzey-doğuya (açıklığa göre $40^{\circ}$ ) yönelik tarzda yatmaktaydı. Yanında birlikte gömülmüş eşyalar: ağaç eyer, üzengi, ağaç kabuğundan yapılmış sadakta yirmi civarında yay oku, yay, demir bıçak, kemer askıları, bronz yüzük, ipek ve bez kumaş parçaları, deri eşya kalıntıları gibi eşyalar bulunmuştur. 


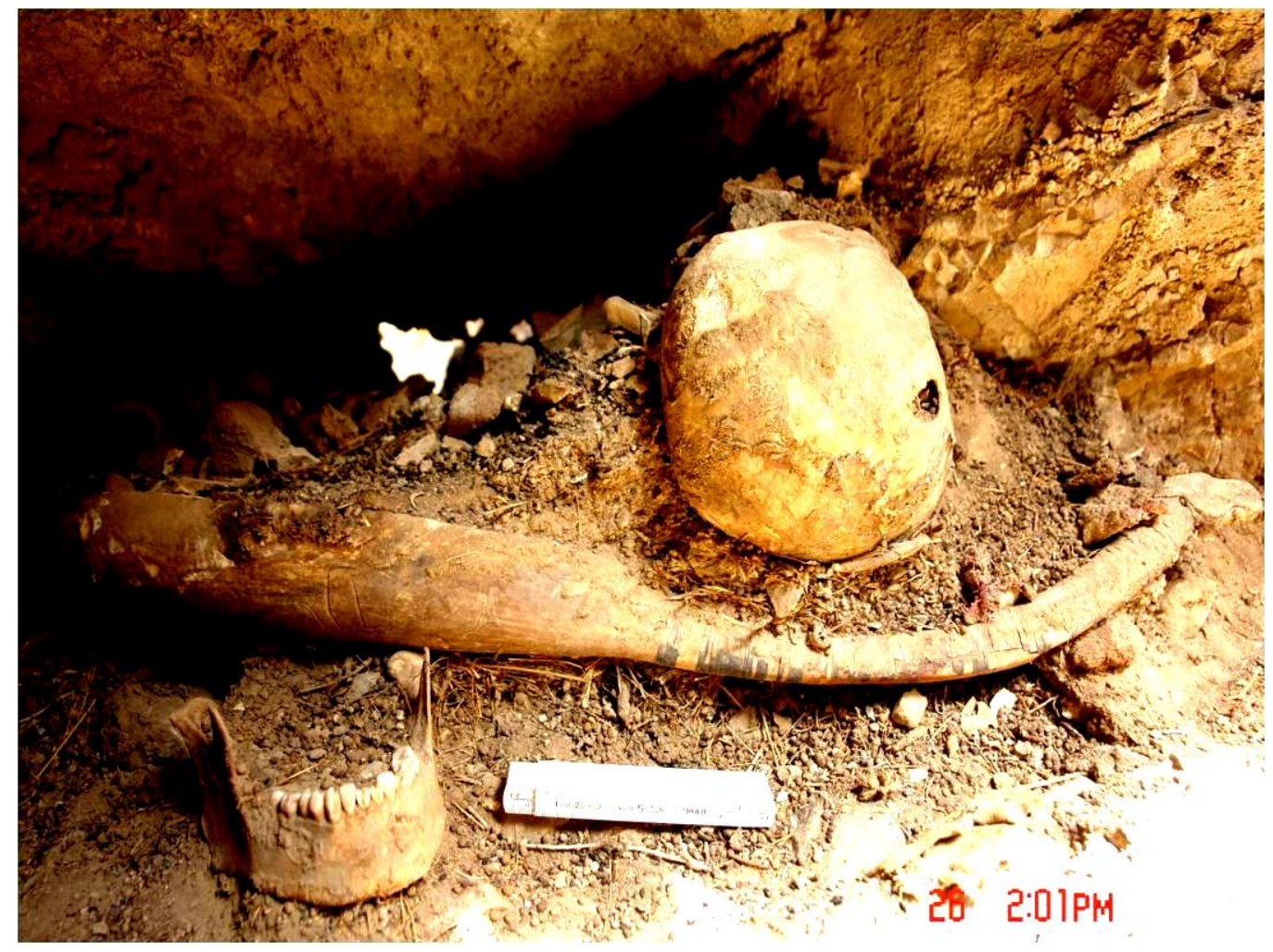

Jargalant-Hayrhan'daki kaya mezarın genel görüntüsü

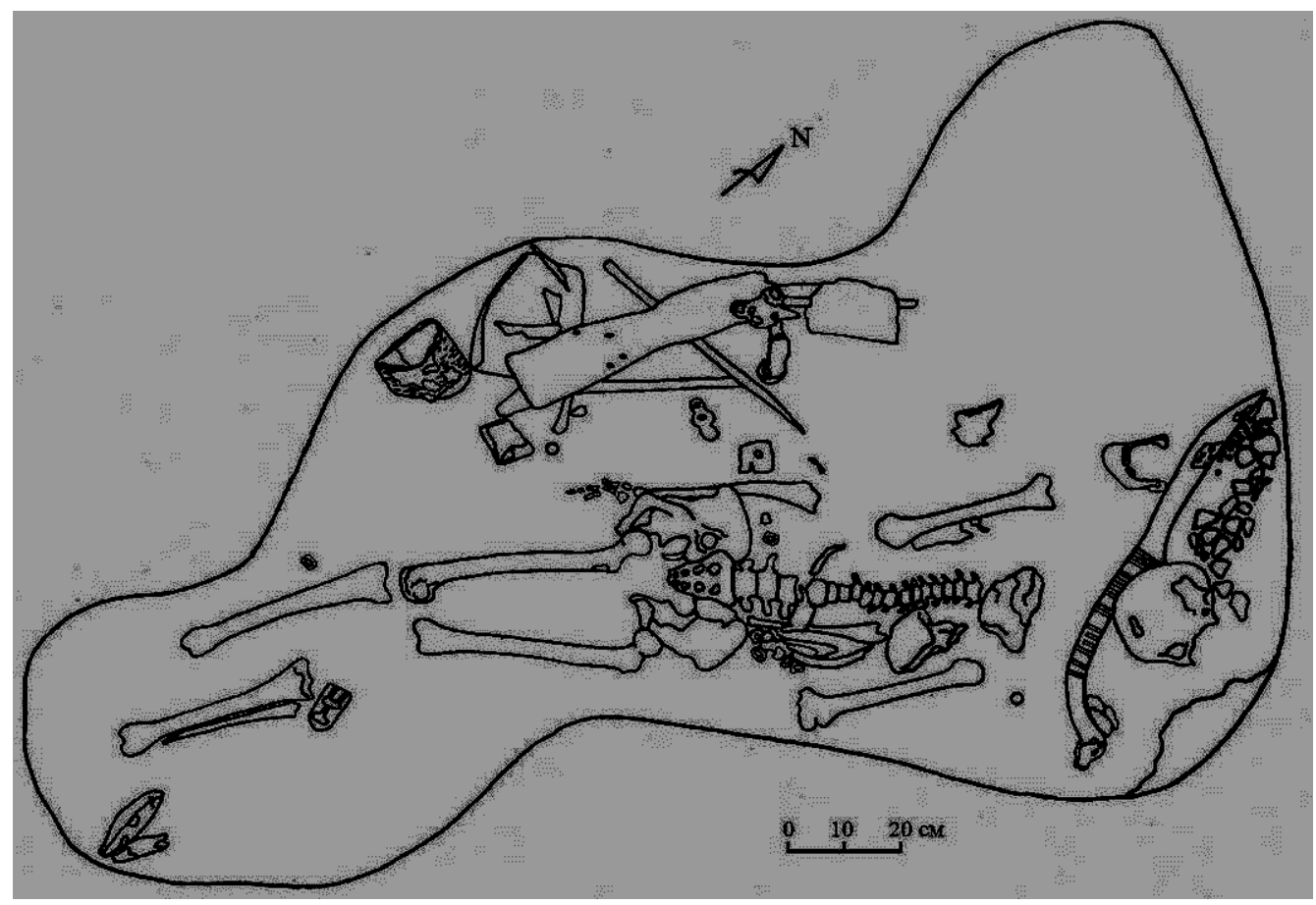

Jargalant-Hayrhan'daki kaya mezar buluntularının çizimi 


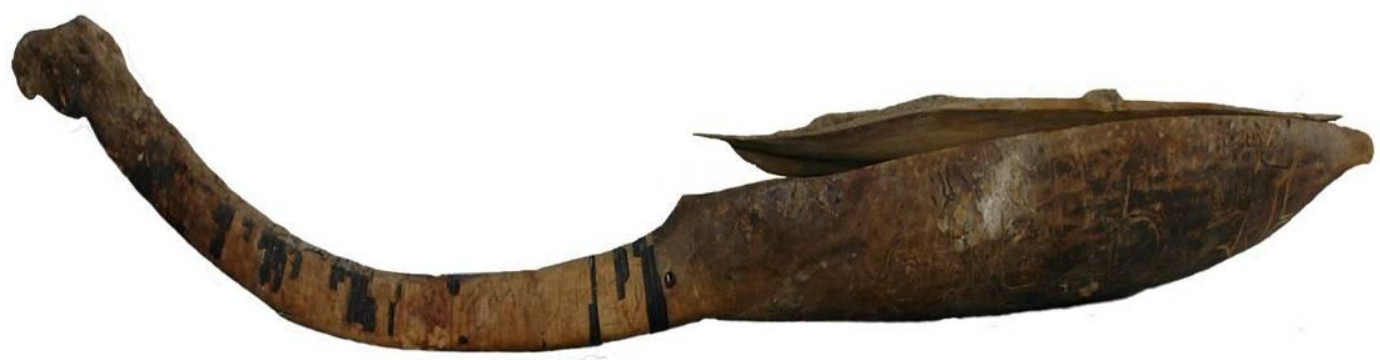

Jargalant-Hayrhan'daki kaya mezarda bulunan kopuzun ${ }^{l}$ görüntüsü

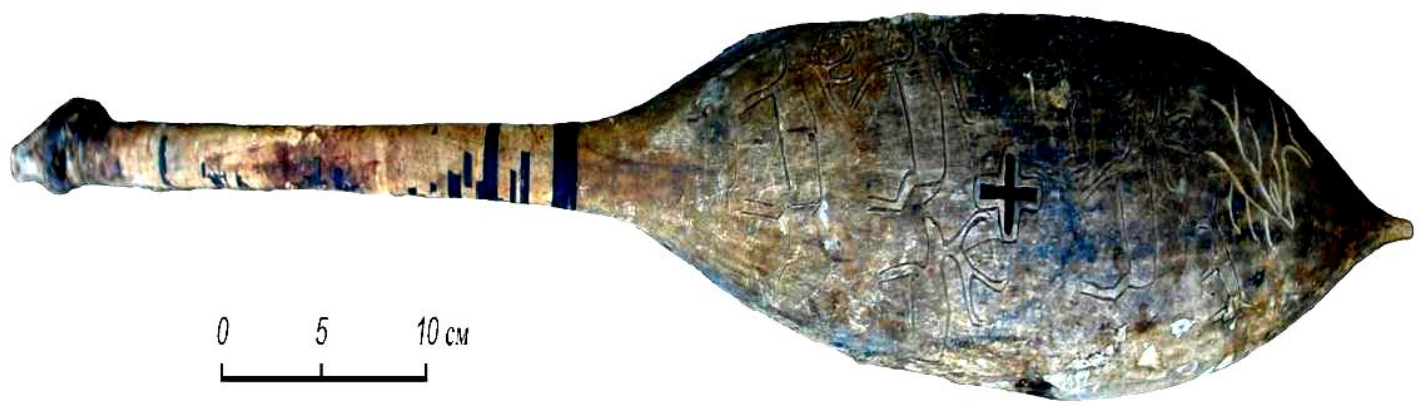

Jargalant-Hayrhan'daki kaya mezarda bulunan kopuzun görüntüsü

Bunlardan en güzel buluntu merhumun başının yanına koyulan ve güzel korunan telli müzik aletidir. Aletin kof gövdesinin üst kısmının üzerinde ve dekasında runik / Köktürk harfli yazıt, gövdesinin alt kısmında ise av sahnesi resmi bulunmaktadır. Aletin üst kısmında hayvan şekli (büyük bir ihtimalle at kafası) oyularak yapılmıştır. Genel olarak bu alet at kafalı morinhuur adlı Moğol yaylı müzik aletine benzemektedir. Ancak, genel özellikleri bakımından Kazak dombrasını hatırlatmaktadır. Herhâlde, bu alet göçebelerin müzik aleti olan morin-huurun prototibi olabilir. Bugünlerden bütün buluntular Almanya laboratuvarlarında restore edilmektedir.

\section{Kaynaklar}

Баяр Д., Мунхтулга Р., Хурэлсух С. Олон нуурын хундийн дурсгал. // Шинжлэх Ухааны Академийн Мэдээ. 2008, № 2, 108-117 (A report on the newly found memorial inscriptions from "Olon Nuur" valley // Proceedings of the Mongolian Academy of Sciences, 2008, № 2, 108-117)

Баяр Д., Мунхтулга Р., Хурэлсух С. “Олон нуурын хундий” гурыптык кешени // Научный мир Казахстана. 5-2008, 109-120

\footnotetext{
${ }^{1} \mathrm{Bu}$ yazının düzenlemesini yapıp görsellerini ekleyen Dr. Cengiz ALYILMAZ’a göre, Jargalant-Hayrhan'daki buluntular arasında yer alan çalgı aleti eski Türk boy ve topluluklarının ortak çalgısı "kopuz"dur. Bu sebeple görüntülerde "kopuz" kavram işareti tercih edilmiştir.
}

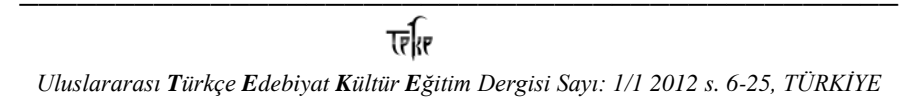


Баяр Д., Мунхтулга Р., Хурэлсух С. “Олон нуурын хундий” гүрыптык кешени // Культурное наследие. № 1 (22) Кантар-Наурыз 2009. 86-89

Батсайхан 3. Шивээт уулын том чулуун байгууламж (Stone construction in Shiveet uul). // Mongolian Journal of Anthropology, Archaeology and Ethnology. Official Journal of the National University of Mongolia. Volume 4 No. 1 (312) December 2008. P. 109-119

Очир А., Одбаатар Ц., Эрдэнэболд Л., Анхбаяр Б. Номгоны турэг дурсгалууд. // Nomadic Studies. International Institute for the Study of Nomadic Civilizations. 16. 2009 , p. $35-47$

Очир А., Эрдэнэболд Л., Одбаатар Ц., Анхбаяр Б. Уйгурын язгууртны бунхант булш // Археологийн судлал. SA, Т. (VI), F. 17. Улаанбаатар, 2008, p. 328-368

Ханс-Георг Хюттель / Уламбаярын Эрдэнэбат. Хар балгас ба Хархорум. Орхоны хундий дэх хожуу нуудэлчдийн суурьшмал хоёр хот (Hans-Georg Huettel / Ulambayar Erdenebat. Karabalgasun und Karakorum. Zwei spatnomadische Stadtsiedlungen im Orchon-Tal). Улаанбаатар, 2009

Турбат Ц., Батсүх Д., Батбаяр Т., Баярхуу Н., Идэрхангай Т. Монгол Алтайгаас илэрсэн хадны оршуулгууд (урьдчилсан ур дун) // Археологийн судлал. SA, T. (VI) XXVI, f. 14. Улаанбаатар, 2008, p. 274-292

Tsagaan Torbat, Dunburee Batsukh, Jan Bemman, Thomas O. Hollman, Peter Zieme. A rock tomb of the Ancient Turkic period in the Zhargalant Khairkhan mountains, Khovd aimag, with the oldest preserved horse-head fiddle in Mongolia - a preliminary report. // Current Archaeological Research in Mongolia. Papers from the First International Conference on "Archaeological Research in Mongolia" held in Ulaanbaatar, August $19^{\text {th }}-23^{\text {rd }}, 2007.365-383$. 